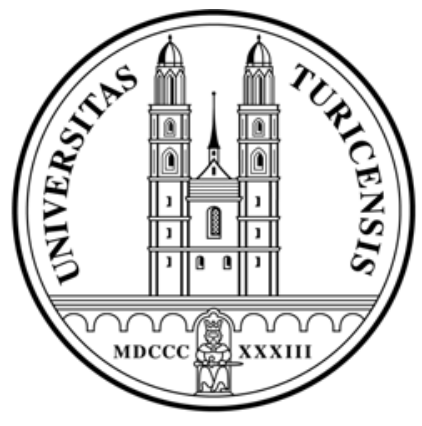

Institute for Empirical Research in Economics

University of Zurich

Working Paper Series

ISSN 1424-0459

Working Paper No. 368

\title{
The Power of Positional Concerns
}

Benno Torgler, Sascha L. Schmidt and Bruno S. Frey

April 2008 


\title{
The Power of Positional Concerns
}

\author{
by
}

Benno Torgler

The School of Economics and Finance, Queensland University of Technology, GPO Box

2434, Brisbane, QLD 4001, Australia, benno.torgler@qut.edu.au

Please address all correspondence to Benno Torgler

Sascha L. Schmidt

Department of Strategy, Organization \& Management, European Business School, International University, Oestrich Winkel, Germany,

Sascha.schmidt@ebs.de

and

Bruno S. Frey*

Institute for Empirical Research in Economics, University of Zurich, Switzerland bsfrey@iew.uzh.ch.

The authors are also associated with CREMA - Center for Research in Economics, Management and the Arts, Switzerland.

Benno Torgler and Bruno S. Frey are also associated with CESifo, Poschingerstrasse 5, D-81679 Munich, Germany

* We wish to thank Margit Osterloh, Eduardo Engel, Bruno Heyndels, Doris Aebi and Rosemary Brown and participants of a seminar at Monash University, the University of Zurich, and Wesleyan University and the ANU (College of Business and Economics), especially Aki Asano, John P. Bonin, Ross Booth, Paul Chen, Alain Cohn, Richard Cornes, Steve Dowrick, Dietrich Fausten, Peter Forsyth, Lorenz Goette, Holger Herz, Joyce Jacobsen, Elias Khalil, Michael Kosfeld, Simon Luechinger, Martin Richarson, Francisco Rafael Rodriguez, Jose Rodrigues-Neto, Masami Imai, Pushkar Maitra, Michael Naef, Susanne Neckermann, Yew-Kwang Ng, Wendy Rayack, Cameron A. Shelton, Gilbert L. Skillman, Russell Smyth, Ben Smith, Farshid Vahid, and Christian Zehnder for their helpful comments and suggestions. 
Abstract: $\quad$ People care a great deal about their relative economic position and not solely about their absolute economic position. However, behavioral evidence is rare. This paper provides evidence on how the relative income position affects professional sports performances. Our analysis suggests that if a player's salary is below the average and this difference increases, his performance worsens. Moreover, the larger the income differences, the stronger positional concern effects are observable. We also find that the more the players are integrated, the more evident a relative income effect is. Finally, we find that positional effects are stronger among high performing teams.

Keywords: Relative income, positional concerns, organizational justice, envy, social comparison, relative derivation, equity theory, prospect theory, loss aversion, performance

JEL Classification: D000, D600, 8222, 9210, L830 
"Throughout history, in all stages of cultural development, in most languages and as members of widely differing societies, men recognized a fundamental problem of their existence and have given it specific names: the feeling of envy and being envied" (Schoeck 1966: 3)

\section{INTRODUCTION}

Francis Bacon (1890) writes in his Essays of Councels, Civl and Moral that "Men of noble birth are noted to be envious towards new men when they rise. For the distance is altered, and it is like a deceit of the eye, that when others come on they think themselves go back" (p. 57). Schoeck (1966) reports several events where people committed homicides due to the feeling of envy: "In 1963, after a basketball game in New York City, a drab-looking day labourer drove his car at the good-looking hero who had won the game and who was standing on the pavement with his parents and friends. The murderer, who had no interest whatever in the losing team, declared that he just could not stand seeing the glamour of that handsome athlete" (p. 129).

Leading figures such as Adam Smith, Karl Marx, Thorstein Veblen or James Duesenberry, have long expressed the importance of the relative position and social concerns. Nevertheless, little attention is paid to the consequences of relative position. Accordingly, Senik (2005), providing an overview of the literature, points out that "it is surprising that in spite of the large theoretical literature on relative income and comparison effects [...] empirical validation of this conjecture is still scarce" (p. 47).

Research on happiness (for example, Easterlin 1974, 1995, 2001, Clark and Oswald 1996, Ng 1997, McBride 2001, Frey and Stutzer 2002a,b, Stutzer 2004, Layard 2003, Luttmer 2005, Ferrer-i-Carbonell 2005) has stressed and found strong empirical support for the importance of the relative position. Also, laboratory experiments, using the ultimatum game, 
indicate that subjects are concerned with their relative position (Frank and Sunstein 2001, Kirchsteiger 1994). Furthermore, as an alternative strategy, some researchers have used hypothetical questions regarding choice between alternative states or outcomes, where the choices allow for checking out relative positional concerns (Alpizar et al. 2005, JohanssonStenman et al. 2002, Solnick and Hemenway 1998, Tversky and Griffin 1993, Zeckhauser 1991). Nevertheless, many researchers are still skeptical of the importance of positional concerns, because empirical evidence about its behavioral relevance remains scarce.

This paper links positional concerns to observable behavior in the field by looking at an individual's work performance. Relative income is certainly a major determinant of people's position. Thus, Frank and Sunstein (2001, p. 347) point out that "[...] positional concerns typically loom larger with income than with the goods that regulation attempts to provide (safety, leisure time, leave to take care of children and ailing relatives)." This paper also contributes to the growing literature that investigates the link between pay and performance. However, contrary to previous studies, we also investigate the relevance of the relative income position. Lazear (2000) points out that theories related to the effects of monetary incentives on work performances were untested due to the fact that appropriate data were unavailable ${ }^{1}$.

A key compensation policy discussed in the literature is that of the promotion tournament. Lazear and Rosen (1981) started to theoretically investigate the behavior of players in response to the incentives created by a tournament ${ }^{2}$. The effect of positional differences on performance is theoretically open. Some theories suggest that the resulting frustration (of those with a low position) leads to resignation and poorer performance. Other theories suggest that a larger positional difference induces individuals to try to achieve a higher position, and hence raises performance. This paper argues that various factors systematically influence which of the two effects is likely to prevail. The more individuals are integrated into a particular social environment, the more differences in relative position lead 
to frustration and poorer performance. The individuals concerned may feel that they have little possibility of changing their social position, so that they tend to resign themselves, thus lowering their performance. In contrast, less well-integrated individuals are less burdened by positional concerns, and a given income difference therefore has little or no effect on their performance.

Empirical analysis of the behavioral impact of positional concerns is hindered by the lack of useful income data. The opportunity of using sports data has led to a growing empirical literature, testing existing theory with sports data ${ }^{3}$ (see Ehrenberg and Bognanno 1990a, 1990b, Becker and Huselid 1992, Orszag 1994, Lynch and Zax 1998, 2000, Fernie and Metcalf 1999, Maloney and McCormick 2000, Melton and Zorn 2000, Sunde 2003). This paper uses sports data to investigate the impact of soccer players' relative income position on their performances. The broad sample covers eight seasons of the German premier soccer league (Bundesliga) between 1995/1996 and 2003/2004 ${ }^{4}$, and includes 1040 players, a salary proxy and several performance variables. The empirical data has low variable errors. Performance is clearly observable and is free of discrepancies, compared to frequently used performance variables, such as GDP. Furthermore, soccer games are comparable to field experiments, due to the fact that a match takes place in a controlled environment. All soccer players are faced with the same rules and restrictions. Thus, when investigating the connection between relative concern and performance, many factors can be controlled for. The paper analyzes to what extent the relative income position of a player affects his sport performance, holding the absolute income level constant. The relative income position is proxied by the difference between teammates' average salaries and players' individual salaries, as well as the difference between league players' average salaries and players' individual salaries. Thus, we investigate two different reference groups ${ }^{5}$. Moreover we look at the effect of future or past salaries on current performance. The empirical results are robust ${ }^{6}$ and consistent with the general hypothesis that the relative position in terms of income 
differences in a team or in the league are, the worse is the performance of the individual players are. These results are robust when controlling for player's skill level or ability and the involvement within a season (number of games and number of minutes played). Moreover, we find that relative income effects are larger in teams with a higher level of pay inequality. The econometric estimates are also consistent with the more specific hypothesis that social integration strengthens this negative effect on performance and that positional effects lowering performance are stronger among high performing teams. The investigation of subgroups also contributes to the discussion of causality issues. If the mechanism were simply that "better players earn more", then we would expect to see the effect of positional concerns in all sub-sample. However, the effect is primarily present for veterans and for top teams and teams with a higher level of income inequality.

Section II provides a short overview of the relevant literature. Section III develops our theoretical approach. Section IV presents the empirical results and Section V discusses implications for business practice and offers concluding remarks.

\section{POSITIONAL CONCERNS: AN OVERVIEW}

Positional concerns due to relative judgments are common. People constantly compare themselves with their environment and care greatly about their relative position, which influences individual choices. Thus, not only is the absolute level of an individual's situation important (e.g., income), but also the relative position, and Frank (1999) emphasizes that research provides "compelling evidence that concern about relative position is a deep-rooted and ineradicable element in human nature" (p. 145). 
Marx (1849) stresses that we measure our wants and pleasures in relation to society. Similarly, Galbraith (1958) points out that consumer demands are largely influenced by society. Veblen (1899) emphasizes the importance of one's relative position in society with his concepts of conspicuous leisure and consumption. Contrary to standard utility theory, Duesenberry's (1949) utility concept is characterized by systematically interdependent utilities. Thus, he explicitly incorporated relative preferences into consumer theory. Marshall (1961), the creator of the modern demand theory, "recognized the power and prevalence of the human desire for 'distinction'” (p. 12).

Social sciences, such as sociology, social psychology, anthropology and economics have placed considerable emphasis on the relevance of relative preferences as fundamental to human motivation. The sociological theory of relative deprivation (Stouffer 1949) and the psychological theory of social comparison (see Festinger 1954) show that comparisons with others are an important phenomenon. Relative deprivation theory investigates interpersonal and inter-group relations and comparisons. It stresses that a lower perception of one's own (group) status or one's own welfare in relation to another person (group) can be the source of hostility towards the other individuals or groups. A person may get frustrated when his/her situation (e.g., individual earnings) falls relative to the reference group. The person feels deprived. If improvement of the situation is slower than expected, the experience of frustration can even lead to aggression (see, e.g., Walker et al. 1984). Several studies also included the concept of interdependent preferences to allow for social comparisons, and have also stressed the relevance of the relative position (e.g., Becker 1974, Easterlin 1974, Scitovsky 1976, Schelling 1978, Pollak 1976, Boskin and Sheshinski 1978, Frank 1985, Ng 1987, Akerlof and Yellen 1990).

As mentioned in the introduction, happiness research has found strong evidence for the importance of relative position. Some empirical studies found behavioral evidence for the extent to which positional concerns matter. For example, Neumark and Postlewaite (1998) 
queried whether women's decisions to seek paid employment depend on the employment or incomes of other women. Thus, they investigated the question of whether relative income comparisons could affect their employment decision. As a reference group, they focused on women's close relatives, but instead of making comparisons between sisters, they investigated whether women's employment is affected by the employment of their sisters-in-law, and whether women's employment is affected by the income of their husbands relative to the income of their sisters' husbands. Their results strongly support the relevance of positional concerns.

\section{THEORETICAL CONSIDERATIONS}

Empirical research on the link between pay and managerial performance has been hindered by the lack of available data in the past (see Lazear 2000). Therefore, a number of researchers use sports data - where performance can be relatively well measured - from disciplines like

golfing (see Ehrenberg and Bognanno 1990a, 1990b; Melton and Zorn 2000; Orszag 1994), horse racing (Fernie and Metcalf 1999; Lynch and Zax 1998), tennis (Sunde 2003), car racing (Becker and Huselid 1992) and running (Maloney and McCormick 2000) in order to test existing theories in promotion tournaments.

The majority of empirical evidence using sports data supports the positive impact of monetary incentives on sportive performance. Using golf data from the US Senior PGA Tour in 1984, Ehrenberg and Bognanno (1990a) found that the amount of prize money has a positive influence on players' performance. The observed effect occurs primarily in the later rounds of a tournament, due to the marginal returns on efforts. Players with larger marginal returns achieve better scores. Ehrenberg and Bognanno (1990b) were able to confirm most of these results, using European PGA Tour data from the year 1987. Only their previous finding, 
that exempt players are more responsive to financial incentives, was not clearly supported by the European data.

Although Orszag (1994) found no statistically significant link between the amount of total prize money and golfers' performance using data from the US Senior PGA Tour of 1992, further studies confirmed Ehrenberg's and Bognanno's (1990a, b) initial findings. For instance, using 1994 and 1995 data, and trying to eliminate any possible survival biases, Melton and Zorn (2000) found support for their theory that the amount of prize money in Senior PGA tournaments affects players' performance. Further empirical support for a positive relationship between pay and performance results from research on tennis tournaments and horse races. Sunde (2003) uses data from the final two rounds of the most important tennis tournaments for professionals - from the men's ATP tour. The results indicate that the amount of prize money positively affects a player's performance, if you count the number of games won and the total number of games played.

Lynch and Zax (1998) examine the role that prizes play in Arabian horse races in the US and Canada between 1991-1995 and find support for a positive relationship between the prize spread and the absolute level of performance. Along the same lines, Fernie and Metcalf (1999) investigate the relationship between pay and performance in an unbalanced panel of 50 individuals over eight years. They find that a hard working jockey receives higher extra pay. Interestingly, the results also demonstrate that reputation lags behind performance or, in other words, that it takes a certain time for good performance to be recognized.

Evidence from sports data supports the proposition that the overall level of performance in a tournament is affected by the amount of prize money paid. Becker and Huselid (1992) use the National Association for Stock Car Auto Racing (NASCAR) 1990 circuit and the International Motor Sports Association (IMSA) data for the years 1989 and 1990. They find that increased variation in the absolute spread between higher ranked and lower ranked finishers has a statistically significant positive impact on participant 
performance, but at a diminishing rate. But little evidence has been found that the actual tournament structure affects performance. Maloney and McCormick (2000) work with data from 115 foot races held in the southeastern United States from 1987 to 1991 . The results indicate that higher prizes are associated with faster times for individuals already in the race and that the higher prizes also attract a faster field. A higher concentration of the prize money leads to higher effort levels. On the other hand, using road races on certified courses in the United States and abroad in 1994, Lynch and Zax (2000) couldn't find a robust impact of a positive prize effect. After controlling for runners' ability through individual fixed effects or world-ranking points, the incentive effect mostly disappears (it remains only statistically significant for the marathon). The results suggest that races with larger prizes lead to faster times, due to the fact that they attract faster runners rather than encourage runners to run faster.

Focusing on team sports, this study goes beyond investigating the performance impact of absolute income by studying the performance impact of relative income. However, the theoretical predictions are countervailing. It is therefore not possible to predict whether larger income differences raise or lower individual performance.

An individual's income is a key factor in comparisons. When people compare their salaries, it is generally with people close to themselves (Layard 2003). Positional concerns are extremely widespread in the workplace. Layard (2003) points out: "In organisations, calm can often be maintained only by keeping peoples' salaries secret” (p. 8). Elster (1991) reports that, in China, model workers spend their bonus on a good meal for everybody to avoid harassment by their colleagues. A manager keeps bonuses low because he fears the other workers and because he wants to avoid the envy of other executive officers. Frank and Sunstein (2001) report that surveys of employers and employees suggest that salaries depend on what employees think other people are paid. Furthermore, the perception of the relative position has a large effect on their morale. 
Festinger (1954) emphasizes that people do not generally compare themselves with the rest of the world, but with a much more specific group, typically with others they see as being similar to themselves or, in his words, "close to one's own ability" (p. 121). Thus, soccer players, like in other team sports, compare themselves with other soccer players, such as teammates or league players in general, due to the same work profile. Similarly, soldiers in World War II seem to have made comparisons primarily with members of their own military group (Stouffer 1949). Thus, it seems reasonable to assume that a soccer player's income position, relative to other teammates' and league players' income position, has an impact on his own behavior.

There are two countervailing theories about how income differences influence performance. One stream of literature stresses the negative consequences of envy (see, e.g., Schoeck 1966). In this case, envy means negative inequity aversion (Grund and Sliwka 2005) and can be characterized by feelings of inferiority, subjective injustice, and longing (Dunn and Schweitzer 2004, Parrott and Smith 1993). An envious person may "prefer that others have less, and he might even sacrifice a little of his own wealth to achieve that end" (Zeckhauser 1991, p. 10), behavior that has been found in experiments (see, e.g., Kirchsteiger 1994). An envious person increases his utility by destroying some of the others' assets, even if such an action carries its own costs (cutting off one's nose to spite one's face). Thus a negative sum interaction is started. The performance of those with lower income may decrease due to frustration ("it could have or it should have been me"). They feel it impossible to "keep up with the Joneses" - in the case of soccer, with the team superstars. As a consequence, performance is lowered. It is even possible that players try to be resentful of the players with a higher salary by, for example, not passing the ball so frequently to reduce their performance.

Relative income effects may include negative aspects that go beyond envy per se. Players dislike being in a lower income position, because the relative position may signal that 
they and their future prospects are lowly evaluated by others. Such perceptions and signals harm their relationship with others, and affect their self-conception and performance.

A contrasting theory argues that large income differences lead to better performance, as they raise the incentive to achieve a similar status. A positional arms race is provoked through the process of rivalry (see Landers et al. 1996).

Our first hypothesis therefore leaves open whether positional income concerns in general have a positive or a negative impact on individuals' performance.

It seems a natural and interesting exercise to investigate to which extent not only the relative income position within a team affects individual performance, but also which mechanisms enforce positional concerns. The level of inequality within a team affects team's climate. Strong differences may reduce the climate quality within the team and provides the ground for positional concern effects. Thus, we would expect that teams with a higher income inequality are more vulnerable to such positional concerns.

The second hypothesis suggests that a larger income difference within a team enforces positional concerns. Thus, positional concern effects are more visible in teams with a stronger income inequality.

The effect of positional concerns is influenced by the pressure to conform. The established members expect new members to adjust to the mores existing in their group or team. Failure to conform is punished, mainly by social sanctions, but sometimes also in other ways (Schoeck 1966). In the case of a soccer team, a newcomer has quite high transaction and adaptation costs. He has to find his place in a team that consists of many players who already know each other well. A player has to gain the acceptance of his colleagues in order to become effective in the team. 
The third hypothesis suggests that newcomers in a team are less influenced by positional concerns. Their performance is less, if at all, affected by the income differences existing in the team.

High performing teams tend to be more vulnerable to positional concerns than low performing teams. In an extraordinarily successful team, each team member tends to associate superior performance with his or her individual performance rather than with other team members. Differences in income negatively affect performance and are therefore less acceptable, while frustration and performance deterioration can be explained using relative deprivation theory. A relatively rapid average promotion rate for the group as a whole tends to lead to frustration about individual promotion rates. The rapid promotion of colleagues in the U.S. Air Corps during World War II inflated soldiers' expectations and resulted in disappointment (Stouffer 1949). In the sports industry, a winner-take-all market exists in many situations. A small number of people get enormous amounts of money compared to other athletes (see Rosen 1981, Frank and Cook 1995). Top teams often have several superstars. For example, Table Al in the Appendix indicates that five of the best paid soccer players in Europe are playing for the same team (Real Madrid). Players in successful teams, who are paid less than other teammates, may be frustrated, which negatively affects their performance. Relative deprivation theory suggests that soccer players feel angry when they lack something they desire, but which other teammates, such as superstars, have. Players feel worse off when they have less fame and money than their teammates with similar attributes, with whom they most frequently compare themselves. Moreover, superstars profit from the success of their team outside of the soccer field. For example, David Beckham, best paid soccer star in 2004 (see Appendix A1) signed a five year 50 million EURO contract with Gillette in September 2004, in addition to multi-million EURO contracts with other 
companies, such as Adidas, Pepsi or Vodafone (see soccer-europe.com). His teammates may well believe that they deserve similar rewards, according to their contribution to the success of the team.

The fourth hypothesis suggests that positional effects lowering performance are stronger among high performing teams.

\section{EMPIRICAL RESULTS}

\section{Data}

Empirical studies of the effects of income differences on managerial behavior have been hindered by the lack of data on individual performance and the lack of publicly available income data. In contrast, in certain sports, individual and team performance is well defined and can be readily observed. This applies to professional soccer. As a side effect, the rising commercialization of soccer led to better data sets. For example, in England, publicly listed clubs must publish their annual reports (Kern and Süssmuth 2003). In some cases (as in the case of the German Bundesliga), even salary data for individual players, or at least good proxies thereof, are available.

This paper uses a unique data set of professional soccer players in the German premier soccer league Bundesliga, which is one of the most important soccer leagues in the world ${ }^{7}$. IMP, the official data provider of the Bundesliga and several broadcasting networks, provided the data. This data includes soccer players' individual performance (e.g. goals, assists, duels won) and personal background data (e.g. age, nationality, position) over a period of eight seasons between 1995/1996 and 2003/2004. We investigate an unbalanced panel of 1040 players covering more than 2000 observations. During the eight seasons, 28 different clubs participated in the league due to annual promotion and relegation. 
Although the salaries of soccer professionals are not officially revealed by the Bundesliga, there is substantial transparency. The most prominent soccer magazine in Germany, the Kicker Sportmagazin, develops players' market value estimates on an annual basis. They provide a good proxy for actual salaries being paid by the clubs ${ }^{8}$. Before a new season starts, the editorial staff develops an estimation of players' market values. This data has been collected in a consistent and systematic manner for several years by almost the same editorial team, and is therefore likely to be consistent. To check the extent to which the market value estimations used in our paper correctly reflect actual salaries, we investigate the correlation between players' effective reported salaries, as provided by another data source called Transfermarkt.de, and our salary proxies. For example, it may be argued that salary estimates are more precise for high-profile players and high-profile teams. This could lead to measurement errors. The Transfermarkt.de data has the advantage of covering salary information for high- and low-profile players, as well as high- and low-profile teams. The correlation between these two data sources is high $(\mathrm{r}=0.754)^{9}$. Thus, measurement errors do not seem to be a major problem. The empirical section will also indicate that the results obtained are robust when dealing with outliers. Moreover, the proxies for salaries are even more satisfactory when analyzing the relative position of soccer players, compared to their teammates and their opponents. In addition, our data set includes individual transfer prices, as well as earnings from ticket sales, merchandizing, and sponsoring revenues at the team level.

\section{Empirical Model}

In the quantitative analysis, four different models are investigated. Investigating the pay-forperformance relationship requires a model that takes into account the incentive effects of absolute and relative pay. Thus, our first model studies whether a player's current performance is affected by his future pay. The model assumes that player's current performance is not affect by the amount of money he has already been paid, but that the factor 
that should matter for current performance is future pay. As data on individuals' perceptions are not available we assume that the best available proxy for individuals' perceptions is the real future pay. The first model has the following baseline equation:

$P E R F_{i t}=\beta_{0}+\beta_{1} C_{T R L_{i t}}+\beta_{2} A B S A L_{i(t+1)}+\beta_{3} R_{E L S A L_{i(t+1)}}+T_{E A M D_{i}}+T D_{t}+{ }_{-} i+\varepsilon_{i t}$

where $P E R F_{i t}$ is the performance of player $i$ at time $t$. Several performance variables, such as goals, assists, shots, ball contacts, duels and duels won are used. These dependent variables refer to active involvement and success in the game. $A B S A L_{i(t+1)}$ is the future salary of a player. To check for non-linearity, the squared value of the salary level is also considered. $R E L S A L_{i(t+1)}$ is the future relative salary of player $i$, measured by the difference between teammates' average salaries and players' individual salaries ${ }^{10}$. The regression also contains several control variables $C T R L_{i t}$ such as AGE, AGE SQUARED, players' position in the game (ATTACK, MIDFIELD, DEFENSE) and team dummy variables (TEAMD $)_{i}$, as many players change their position in the field and in their team over time. Team dummy variables are included, as it can be argued that the results are driven by unobserved team characteristics that are correlated with income and performance. Team fixed effects allow us to control for such possible omitted variable bias. However, estimates without team effects are also reported in order to go beyond a within team focus. Similarly, the estimates include a set of time dummies $\left(T D_{t}\right)$ to control for possible differences in the players' environment; ${ }_{i} i$ is the individual effect of player $i$, and $\varepsilon_{i t}$ denotes the error term.

A model using future pay assumes that a player is able to predict his and other players' future income situation, and therefore his relative income position. However, experimental studies suggest that individuals have difficulty in predicting their future utility and tastes (for an overview, see, for example, Loewenstein et al. 2003). To avoid such criticism, we check the robustness of the results, using past rather than future earnings as a reference point, as it 
can be argued that players' performance is less likely to be affected by the amount of money already paid out. On the other hand, we may still observe incentive effects, as we investigate the relative income position of a player. Positional concerns due to the past income position may affect current performance. Thus, our second baseline specification has the following form:

$P_{E R F_{i t}}=\beta_{0}+\beta_{1} C_{T R L_{i t}}+\beta_{2} A B S A L_{i(t-1)}+\beta_{3} R_{E L S A L_{i(t-1)}}+T E A M D_{i}+T D_{t}+{ }_{-} i+\varepsilon_{i t}$

where $A B S A L_{i(t-1)}$ is the player's lagged absolute salary and $R E L S A L_{i(t-1)}$ is the player's lagged relative salary.

The two previous models take into account that teammates serve as the reference group. We also consider a player's salary relative to the entire league, rather than the player's team. The pay of superstars and players in high profile teams might be even more salient to players and the general public than the pay of members of one's own team. Publicly available data on incomes increase transparency and therefore provide players with information as to what other league players get paid. Moreover, as the soccer player market is quite homogenous in the sense of an equal job profile, players tend to compare themselves with other players in other teams. The third and fourth baseline specifications take the following form:

$P E R F_{i t}=\beta_{0}+\beta_{1} C_{T R L_{i t}}+\beta_{2} A B S A L_{i(t+1)}+\beta_{3} \operatorname{RELSALL}_{i(t+1)}+\operatorname{TEAMD}_{i}+{ }_{i}+\varepsilon_{i t}$

and

$P E R F_{i t}=\beta_{0}+\beta_{1} C_{T R L_{i t}}+\beta_{2} A B S A L_{i(t-1)}+\beta_{3} \operatorname{RELSALL}_{i(t-1)}+\operatorname{TEAMD}_{i}+{ }_{-}{ }+\varepsilon_{i t}$ 
where $R E L S A L_{i(t+1)}$ and $R E L S A L_{i(t-1)}$ are defined as the future or past relative salary position of player $i$, measured as the difference between the leagues' average salaries and the player's individual salary.

\section{Pay and Performance: Basic Results}

We first apply three different methodologies (pooling regression, random effect model and fixed model) to all available performance measures. To identify which empirical method is most suitable, we performed two statistical tests: the Lagrangian Multiplier (LM) test (see Breusch and Pagan 1980) of the random effect model and the Hausman specification test (Hausman 1978) in order to compare the fixed effect and the random effect models. The LM test indicates that the null hypothesis of the individual effect ${ }_{-}{ }^{\text {being }} 0$ is rejected in all cases at the $1 \%$ significance level. Thus, the results suggest that the cohort effect is not zero, which means that the pooling regression is not suitable. In all cases, the Hausman specification test rejects the null hypothesis that the individual-level effects are adequately modeled by a random effect model at the $1 \%$ significance level. Thus, individual effects are not uncorrelated with the independent variables, which support the use of individual fixed effect models. However, it should be noted that the results we obtain remain robust with all three methodologies.

Table 1 presents the basic estimation results of our first model, using the entire set of six dependent variables, representing various aspects of players' performance: goals, assists, shots, ball contacts, duels and duels won. In all regressions, we observe that all the coefficients of RELSAL are negative. If a player's salary is below the average and this difference increases, his willingness to perform decreases and the negative effect of positional concerns are more visible. At the same time, the positive impact of an above-average salary change towards a stronger difference in relation to the teammates is also observable. The 
respective coefficients are highly statistically significant for all six dependent variables, controlling for the absolute level of the salary. This finding is consistent with the first hypothesis that the relative income level has an impact on performance, and the theories proposing that a disadvantage in the relative income position worsen performance. The coefficient of absolute income indicates a statistically significant positive impact on individual performance, and the squared term, which is statistically significant with a negative sign, indicates a non-linear relationship between salary and performance. Thus, an increase in the salary beyond the turning point can lead to a harmful reduction in individual performance. We also perform estimates without team fixed effects to counter the argument that the "within team findings" indicate that teams get it more or less right, or that those who are paid worse relative to their teammates also perform worse relative to their teammates. However, the coefficient of the relative income variable remains highly statistically significant in all 6 estimates, excluding team fixed effects. We also test the joint hypothesis that the absolute and the relative income as a group have a coefficient that differs from zero. The results in Table 1 indicate a clear rejection of this hypothesis, which supports the importance of the income variables as a group. Looking at the control variables, we can also observe that age tends to influence performances, such as duels and shots, having a concave performance profile - that is, rising with age but decreasing as physical condition worsens.

\section{[TABLE 1 ABOUT HERE]}

In Table 2, we run the same 12 regressions, but instead of using future salary, we take past salary. We also differentiate between estimates with and without team fixed effects. The importance of the relative income position is supported in Table 2. All coefficients are statistically significant. Moreover, based on an $F$-test for the joint significance of the relative 
and absolute income, it can be argued that, as a group, they significantly influence individual performance. Table 2 also indicates that player characteristics are important.

The next step investigates the impact of positional concerns when changing the reference group. We therefore look at a player's salary relative to the entire league rather than the player's teammates. The first part of Table 3 provides the results of these 24 regressions. For simplicity, only the income coefficients are reported. As can be seen, there is still a strong relative income effect. Moreover, the joint significance of the relative and absolute income variable suggests that these two variables together play a significant role in the determination of performance.

\section{[TABLE 2 ABOUT HERE]}

\section{Robustness Tests}

This subsection presents several robustness tests. First, we include as a control variable the number of games played per season ${ }^{11}$. As can be seen in Table 3, the results remain robust. We also obtain similar findings when controlling of the minutes played per season. It is highly relevant to control theses robustness tests, otherwise one could criticize that players with relatively low salaries are less skilled and get less time on the field, and hence perform worse. In a next step we use as dependent variables the number of goals, assists, shots, ball contacts, duels and duels won per game as the dependent variable. The results also remain robust. We control for ability since player fixed effects pick up any omitted variables (player characteristics) that do not change over time. Using eight seasons one can argue that over such a period, ability has a fixed and a variable portion. For example, a player's ability grows initially peaks and then declines prior to retirement, but throughout this cycle the player's ability stays above a player-specific threshold. How can we control for the portion that changes over time? To a certain extend such an effect is controlled with the variable age. In 
addition, one can cluster the standard errors by player since clustering will pick up any playerspecific characteristics that change over time. Thus, we also perform pooled estimations with team and time dummy variables, using the number of minutes played as weight unit to take into account unobservable players' specific characteristics, with standard error adjusted for the clustering on individuals. Also in these estimates, the previous results remain robust. In a next step, we investigate whether the results react sensitively to outliers. Therefore, we also run specifications that resist the pull of outliers, using iteratively reweighted least squares with Huber and biweight functions tuned for 95\% "Gaussian efficiency" (see Hamilton 2004, pp. 239-240). As a consequence, more extreme outliers are less heavily weighted in the regression calculations, or even dropped altogether in very extreme cases. We present estimations using all four models. The results of the 24 regressions are presented in the second part of Table A3. The previous findings remain robust. In all 24 cases, the coefficient of the relative income variable is statistically significant at the 1 percent level, with a negative sign. There is also support for a positive non-linear relationship between absolute income and performance. Moreover, in line with previous results, we observe that, as a group, the relative and absolute income variables are jointly significant in all estimates.

\section{[TABLE 3 ABOUT HERE]}

What happens when a team hires some new superstar players? Lucifora and Simmons (2003) define superstar players that reach more than 0.40 goals per game. We extend this definition including also those players that reach more than 0.40 assists per game as superstars. A new superstar may have a strong impact on the team. First, the relative pay in a team falls when it hires some new superstar players and may influence the performance of other players. Thus, we investigate whether the relative income effects remain robust after controlling for new 
stars in a team. The previously obtained results remain robust, showing that RELSAL is highly statistically significant with a negative sign.

Existing studies on the relative income position normally calculate how far apart a person's situation is from the respective reference group. As a further robustness test, the ratio of teammates' income to players' own income is used as proxy for the relative income position (the higher the value, the stronger the disadvantage in the relative income position). This calculation may be relevant in the following situation: A player has an average annual income of $\$ 100^{\prime} 000$ in a soccer team, where his teammates earn on average $\$ 200$ ’000 per year. The team management decides to double the salaries of all the team members. In the new constellation, the player now receives $\$ 200^{\prime} 000$, while his teammates get $\$ 400^{\prime} 000$ on average. The ratio remains constant (value 2), but the difference has changed from $\$ 100$ '000 to $\$ 200 ’ 000$. The regression results support the previous findings.

Furthermore, instead of pooling the different years together, each year is investigated in a cross-sectional analysis. In this case the coefficient RELSAL can be interpreted the following way: the more my salary is below the average, the worse is my performance and at the same time, the more my salary is above the average, the better is my performance, controlling for the absolute income. Likewise in these cases, relative income effects are observable and therefore results obtained previously are supported. Finally, we also take a closer look at possible team effects. Previously, possible effects were controlled for using, in the majority of cases, team fixed effects. The regression can be extended, using proxies for teammates' strength. Player performance varies in different settings, as co-workers offer different levels of assistance (Idson and Kahane, 2000, Torgler 2006). Team composition has a strong impact on team productivity (Hamilton, Nickerson and Owan 2003). Complementarities in production, and gains from specialization in the form of accumulated task-specific human capital, are valuable to other team members (see Lazear 1998). Three aspects are included: teammates' age, exchanges and sending-offs in a game per season. 
Teammates' impact on a player $i$ is measured by calculating the average values for the teammates (excluding the values for player $i$ ). More exchanges may be correlated with higher individual performance, because of an increase in the teammates' average physical strength. Similarly, higher exchange values may also be an indicator of good second line players. On the other hand, expulsions have a strong negative impact on the probability of winning a game, because losing a teammate reduces the team's strength (for empirical evidence, see Torgler 2004). Specifically, the team structure must be reorganized, which, because soccer skills are highly specialized, tends to reduce players' and team-mates' comparative advantage. The results indicate that the coefficients of the relative income variable remain statistically highly significant. Moreover, the joint hypothesis that none of the salary variables (absolute and relative income position) has a coefficient that differs from zero can clearly be rejected. The results also indicate that teammates are important. Based on an $F$-test for joint significance, teammate factors play a significant role in the determination of individual performances. Particularly strong effects are observed for the variable exchanges (positive) and sending-offs (negative). The impact of teammates' age (negative) is less robust and not always statistically significant.

\section{Income Inequality, Newcomers and Top Teams}

In this subsection we are going to separate teams with a higher income inequality from those with a lower income inequality and also top teams from others. Moreover, we are going to separate new players from veterans. This section allows evaluating not only our discussed hypotheses, but also contributes to the issue of causality, which will be discussed in the next section. If the mechanism is simply that better players earn more then we would predict that the effect of the relative income position is visible in all sub-sample, However, we will see that this is not case. 
Table 4 provides the first results summarizing 72 estimates, differentiating between teams with a higher income inequality and teams with a lower one. In order to split the sample, the mean team GINI coefficient over the investigated period was calculated. The teams ranked above average were placed in one group labeled "higher income inequality", and the remaining teams were placed in the other group. The results suggest that players in teams with a higher income inequality are indeed more vulnerable to the consequences of income differences than players in less successful teams. Thus, hypothesis 2 cannot be rejected.

\section{[TABLE 4 ABOUT HERE]}

Table 5 presents the findings of the estimates, referring to the behavioral consequences of positional concerns of newcomers in a team compared to players already integrated into the team (for at least one season). The sample of players is split between newcomers and integrated players. Due to many team changes in our data set, this issue can be empirically investigated. All four models are taken into consideration. The first part focuses on models with teammates as a reference group, using future and past incomes. The second part uses league players as a reference group. The regressions clearly show the tendency that, in line

with hypothesis 3, newcomers are less driven by positional concerns. In only a few regressions is the relative income coefficient statistically significant for newcomers. In contrast, in the sub-sample of integrated players, the coefficients are mostly statistically significant, with a negative sign. This result is consistent with the hypothesis that integrated players resent differences in income more intensely than newcomers, diminishing their performance accordingly if they are below the teammates' average salary. The question remains whether changing teams is correlated with ability or, in other words, whether stayers are worse off compared to movers, as they may not have received very tempting offers from 
other teams. Thus, it is checked whether transferring to another team is correlated with ability. The proxy for ability is taken to be a selection for the national team or the performance in the past season before changing teams. The results suggest that changing teams is not correlated with ability.

\section{[TABLE 5 ABOUT HERE]}

Table 6 finally reports the results referring to hypothesis 4, proposing that high performing teams experience stronger relative income concerns than low performing teams. In order to split the sample, the mean team performance over the investigated period (the rank at the end of each season) was calculated. The teams ranked above average were placed in one group labeled "top team", and the remaining teams were placed in the other group. The results suggest that players in top teams are indeed more vulnerable to the negative (and also positive) consequences of income differences than players in less successful teams. Table 6 summarizes the results of 72 regressions. In most of the cases, the respective coefficient is statistically significant, with a negative sign, so that the performance of the players declines if disadvantage in the relative income position increases. On the other hand, players' performance in teams with lower performance levels is less affected by their relative income position. The question arises as to whether salaries are a better predictor of actual ability in better teams. Results for future earnings are also presented.

\section{[TABLE 6 ABOUT HERE]}

\section{Causality}

In general, the direction of the link between income and performance is unclear and has rarely been investigated in detail in the literature. It may be argued that lower-paid players might 
perform worse because they are not such good athletes; which means that poor performance results in lower pay, not the other way around. However, as mentioned previously, if the process was simply that better players earn more, then you would not expect to see our previous findings that report that the relative income effect is not anymore visible in certain sub-samples.

\section{Overview}

In the first part of this subsection we are going to summarize previous findings that have tried to investigate carefully the relationship between pay and performance (mainly at the team level). The main problem is, as Hall et al. (2002) point out, that such a link "plays a central role in the theory of team sports but is seldom investigated empirically" (p. 149). In general, looking at the empirical research available today, most soccer studies investigate players' income or teams' income as the dependent variable and search for factors that affect it (Eschweiler and Vieth 2004, Garcia-del-Barrio and Pujol 2004, Huebl and Swieter 2002, Lehmann and Weigand 1999, Lucifora and Simmons 2003, Lehmann and Schulze 2005). For the German soccer league, Eschweiler and Vieth (2004), Huebl and Swieter (2002), Lehmann and Schulze (2005), as well as Lehmann and Weigand (1999), confirm a positive payperformance relationship. Only a couple of studies take team performance as the dependent variable (see Forrest and Simmons 2002, Szymanski and Kuypers 1999). Investigating whether club expenditures have a positive impact on the team's success within the English soccer league, Szymanski and Kuypers (1999) find a significant correlation between a team's pay and a team's performance. Using data from Italian, English, and German soccer leagues, Forrest and Simmons (2002) find a strong team pay-performance relationship for the leagues in Italy and England. On the other hand, only a marginally significant wage-performance relationship has been found for the German Bundesliga. However, as mentioned by Hall et al. (2002), the causality has seldom been investigated. Do teams really get what they pay for? 
Some studies focusing on baseball doubt whether this is the case, suggesting that payrolls are not useful in explaining the won-lost records in baseball (Quirk and Fort 1999, Zimbalist 1992). On the other hand, Hall et al. (2002) show with their data that, while there is no evidence that causality runs from pay to performance over the period 1980 to 2000 , the crosssection correlation between pay and performance increased significantly in the 1990 s. They also found support for the relationship running from payroll to performance, and not vice versa, when investigating the relationship between a team's pay and a team's performance for English soccer data using the Granger causality test. Such differences can be explained by institutional differences affecting causality between different sports or sport periods. In English soccer, players are hired on relatively short-term contracts, ranging from one to five years, and players' trading and mobility are key parts of the league. The mobility costs are also lower, due to the relative geographic proximity to each other. Moreover, young stars at the beginning of their career are more mobile, which is comparable to the stars of the league, where trade clauses are "virtually unheard of in English soccer" and "leading teams regularly trade their top stars in search of a better lineup, whereas players frequently express their ambition to play for a variety of clubs in a variety of leagues during their career" (p. 158). These factors are also visible in the German Bundesliga. Our data indicates that the number of active seasons in the league per player varies between one and eight, with an average of 2.7 seasons per player. A change of team has been observed in $12.7 \%$ of the cases. Similarly, Carmichael, Forrest and Simmons (1999) report that, in the English league, $12.3 \%$ of the players changed teams in the seasons 1993-1994. Moreover, Dobson and Goddard (1998), using a data set covering 77 football leagues between 1946 and 1994, find evidence of reverse causality; specifically, that the influence of lagged revenue on current performance is greater than the influence of lagged performance on current revenue. Davies et al. (1995), who focus on professional rugby league matches between 1964 and 1993, use attendance rather than revenues, but find similar results for the direction of causality. 


\section{2SLS and Granger Causality Test}

The previous subsection does not provide us a lot of empirical support that causality runs from team performance to team salary. On the contrary, there is the tendency that pays affects performance rather than the other way round. However, currently only a limited number of studies are available to get a robust picture of such a relationship. Our first attempt was to use experts' salary estimates of future or past income to deal with causality. Furthermore, experts' evaluations attempt to measure the market salary of a player rather than the contract salary, which might remain constant for more than one year. In a next we have built sub-samples finding strong differences, which indicates that the argument "better players earn more" is too simplistic. In a next step, we continue to deal with this important issue, performing a Hausman specification test, running several 2SLS estimations and providing Granger causality tests.

In Table 7, we report 2SLS estimations together with several diagnostic tests and the first stage regression results. Table 7 indicates that for the 2SLS, the coefficient of the variable RELSAL remains statistically significant with negative sign. Moreover, coefficients for RELSAL are not smaller compared to the previous table, suggesting little reverse causation between current performance and past or future salary. If reverse causation biased the coefficient for the relative income variable upward in previous tables, the coefficient estimated using 2 SLS should be smaller ${ }^{12}$. First we perform a Hausman specification test, to whether there is sufficient difference between the coefficients of the instrumental variables regression and those of the standard regression (see Hausman 1978). The Prob $>$ chi2 statistics indicate that we cannot reject the hypothesis that the standard regression is a consistent estimator for our equation, which supports the argument that there is no endogeneity problem with our estimates. 
To check the robustness, we use two different instruments for RELSAL. Teams' income inequality structure might be a good starting point to identify a valid and strong instrument. We have seen previously that teams with a higher income inequality are more affected by relative income effects. The question is whether income inequality also affects player performance directly. Controlling for income inequality in the estimations leads to the results that income inequality does not affect performance directly. The coefficient was not statistically. On the other hand, our previous results indicate that income inequality enforces the relative income effect. Thus, we use the GINI coefficient as an instrument for the relative income position. As a second instrument we include nationality or in other words whether a player is a foreigner or not as an instrument for the relative income position. Foreign players may be subject to more pressure to conform than domestic players which affects the strength of relative income effect. As an instrument for the absolute income we take the number of spectators at home in the past season. A higher level of spectators in the last season is connected with higher revenue in the past, which should affect players' current salary.

Table 7 presents a selection of 2SLS estimations that we conducted. The relative income effect is still visible. The coefficient RELSAL is statistically significant in all regression at the 1 percent level. Similarly, also the $F$-test for joint significance of the relative and absolute income position is statistically significant at the 1 percent level. The results show that the instruments are effective in explaining the relative and absolute salary. All factors are statistically significant at the $1 \%$ level. Moreover, the $F$-tests for the instrument exclusion set in the first-stage regression are also statistically significant in all cases at the $1 \%$ level. In addition, Table 7 reports a test for instrument relevance using the Anderson canonical correlations LR for whether the equation is identified. The test shows that the null hypothesis can be rejected, indicating that the model is identified and the instruments are relevant (see Hall, Rudebusch and Wilcox 1996). The Anderson-Rubin test suggests that the endogenous variables are in most of the cases jointly statistically significant. Such a test is robust to the 
presence of weak instruments. The partial R2 is checked to take into account that there is more than one endogenous variable (Shea 1997). The Shea's partial R-squared is a test of the individual explanatory power, accounting for correlation among the instruments. These results are not reported in Table 7, but the findings (closeness of the Shea's R-squares) indicate that there is enough separate variation in the instruments.

\section{[TABLE 7 ABOUT HERE]}

The next step performs a Granger-causality test to investigate the link between pay and performance (see Granger 1967). The notion of Granger causality suggests that, if lagged values of players' income helps predict current performance values in a forecast (formed from lagged income and lagged performance values), then income Granger causes performance. On the other hand, if the same lagged values help to predict current income, we argue that performance Granger causes players' pay (similar arguments apply for the future income model). A unidirectional causality from one to the other must be identified. To perform the Granger causality test, symmetric regression tests for the future and past income model are applied. They include the six performance variables and the relative and absolute income position independently. Table 8 presents the results of 12 Granger causality tests using the future income model. The results show that non-causality between income and performance can be rejected. At the same time, it fails to fully reject consistently the non-causality between performance and income (relative or absolute). Thus, the test results indicate a rejection of the hypothesis that income does not Granger cause performance but not a full rejection of the hypothesis that performance does not Granger cause income. Thus, there is a tendency that income seems to cause performance in stronger manner than performance cause income. However, results obtained with the past income model are less obvious. 


\section{CONCLUSIONS}

The empirical results presented suggest that not only the absolute, but also the relative income position, has an impact on individuals' performance. If a player's salary is below the average and this difference increases, his willingness to perform decreases and the negative effect of positional concerns are more visible. At the same time, the positive impact of an aboveaverage salary change towards a stronger advantage in relation to the teammates is also observable. The cross-sectional analysis also shows that the more the salary is below the average, the worse is the performance and the more a player's salary is above the average, the better is his performance. We also investigate what factors lead to a stronger relative income effects. We find that such effects are stronger among teams with a higher level of income inequality. Furthermore, more integrated members of a team react more negatively than newcomers, resulting in diminished performance. Moreover, players in top teams also react more negatively than players in other teams.

To what extent can these findings on soccer players' behavior be transferred to business practice? What can managers learn from them? First of all, the results are relevant for the design of incentive mechanisms. Positional concerns are important in areas where measurable performance is directly linked to salary (pay-for-performance). For instance, in many sales organizations, it is common practice that sales commissions make up a large part of the total salary. Thus, insurance agents or financial advisors are paid according to key sales performance indicators, such as net new money, return on assets, and the number of products or policies sold within a certain period. In order to stimulate internal competition among the sales force, and to push individual performance, transparency is increased by comparative performance rankings among the sales force. Given that performance directly translates into personal income, such rankings run the risk of diminishing, rather than improving, 
performance among those below the average. The most successful sellers, who dominate the rankings and earn much more than their colleagues, may well weaken the performance of the entire sales team if their performance is not able to compensate the loss generated by those salesmen that lower their performance. Moreover, it is important to take into account that a higher level of inequality enforces position concern effects.

Pay-for-performance schemes are usually linked to output measures neglecting process- or context-specific factors. Accordingly, sales people at the lower end of the ranking may see that higher ranked colleagues are not performing better, but simply benefit from lucky punches or advantageous context factors (e.g., the districts they cover have a higher number of potential clients). Although pay-for-performance schemes are helpful to identify low performers, they may tend to lower the average performance of the team. A positional arms race may be provoked through the process of rivalry (Landers et al. 1996), but our results don't support such a tendency. This downside risk is even bigger for top performing teams, just as individuals playing in top soccer teams are more vulnerable to the negative consequences of a relative income disadvantage. Top performing sales teams may already have ambitious and self-motivated team members so that further stimulation of internal team competition leads to negative motivational effects. Thus, management is faced with the difficult task of finding the right amount of 'healthy competition' within a team. It is a challenge of calibrating the wage offers in such a manner to generate the most favorable effect possible on the effort of other workers, as well as to extract the appropriate effort from the worker to whom they are directed.

Pay-for-performance schemes address extrinsic motivation, and leave intrinsic motivation aside. According to Frey and Osterloh (2005), such schemes tend to reinforce selfish extrinsic motivation, crowding out intrinsic motivation. Managers need to consider the motivational aspects of the transparency of relative income positions in terms of corresponding benefits and downside risks. Negative effects of output-oriented financial 
incentives, such as pay-for-performance schemes, should be complemented with processoriented non-financial incentives, such as awards for the best team player, best rookie, or most innovative team member of the year. This takes into account the individual's need for social distinction, using a non-material extrinsic reward (see Frey 2005). The empirical results are also relevant for the treatment of new employees joining an established team. The findings suggest that newcomers are less driven by positional concerns than existing team members. Newcomers' performance is less affected by a disadvantage in the relative position. Conformism, adaptation, adjustment and short-time satisfaction due to the change (which is often connected with an absolute salary improvement) may account for these differences. In business practice, managers often switch jobs in order to increase their salary (e.g., in investment banking). Employees joining a new firm are therefore less affected by a disadvantage in their relative income position. However, over time, newcomers get used to their new situation and start comparing their performance/income relation with the new reference group. Management needs to take into consideration that, after an initial adaptation period, newcomers base their income expectations on their relative position in the team. As a result, a perceived disadvantage in the performance/income relationship tends to lead to behavioral changes. 
Table 1: The Effect of Positional Concerns within the Team on Performance (Future Earnings)

\begin{tabular}{|c|c|c|c|c|c|c|c|c|c|c|c|c|}
\hline Independent Variables & \multicolumn{2}{|c|}{$\begin{array}{l}\text { Dep. V.: Goals } \\
\text { FE }\end{array}$} & \multicolumn{2}{|c|}{$\begin{array}{l}\text { Dep. V.: Assists } \\
\text { FE }\end{array}$} & \multicolumn{2}{|c|}{$\begin{array}{l}\text { Dep. V.: Shots } \\
\text { FE }\end{array}$} & \multicolumn{2}{|c|}{$\begin{array}{l}\text { Dep. V.: Ball Contacts } \\
\text { FE }\end{array}$} & \multicolumn{2}{|c|}{$\begin{array}{l}\text { Dep. V.: Duels } \\
\text { FE }\end{array}$} & \multicolumn{2}{|c|}{$\begin{array}{l}\text { Dep. V.: Duels Won } \\
\text { FE }\end{array}$} \\
\hline SALARY & & & & & & & & & & & & \\
\hline $\operatorname{RELSAL}(\mathrm{t}+1)$ & $\begin{array}{l}-0.377^{* * *} \\
(-6.00)\end{array}$ & $\begin{array}{l}-0.256^{* * *} \\
(-2.70)\end{array}$ & $\begin{array}{l}-0.232 * * * \\
(-3.98)\end{array}$ & $\begin{array}{r}* 0.128 \\
(-1.45)\end{array}$ & $\begin{array}{l}-3.943 * * * \\
(-9.37)\end{array}$ & $\begin{array}{l}-3.093 * * * \\
(-4.94)\end{array}$ & $\begin{array}{l}-64.999 * * * \\
(-4.31)\end{array}$ & $\begin{array}{l}-32.780 \\
(-1.50)\end{array}$ & $\begin{array}{l}-42.514 * * * \\
(-9.19)\end{array}$ & $\begin{array}{l}-24.140 * * * \\
(-3.48)\end{array}$ & $\mid \begin{array}{l}-19.459^{* * *} \\
(-8.38)\end{array}$ & $\begin{array}{l}-9.670^{* * *} \\
(-2.78)\end{array}$ \\
\hline ABSAL $(t+1)$ & $\begin{array}{l}0.663^{* * *} \\
(7.24)\end{array}$ & $\begin{array}{l}0.776^{* * *} \\
(6.92)\end{array}$ & $\begin{array}{l}0.641^{* * *} \\
(7.54)\end{array}$ & $\begin{array}{l}0.740 \\
(7.10)\end{array}$ & $\begin{array}{l}3.450^{* * *} \\
(5.63)\end{array}$ & $\begin{array}{l}4.276^{* * *} \\
(5.75)\end{array}$ & $\begin{array}{l}109.682 * * * \\
(5.08)\end{array}$ & $\begin{array}{l}134.766^{* * *} \\
(5.30)\end{array}$ & $\begin{array}{l}45.353^{* * *} \\
(6.73)\end{array}$ & $\begin{array}{l}62.414 * * * \\
(7.60)\end{array}$ & $\begin{array}{l}23.364^{* * *} \\
(6.91)\end{array}$ & $\begin{array}{l}32.393^{* * *} \\
(7.85)\end{array}$ \\
\hline SQ ABSAL $(\mathrm{t}+1)$ & $\begin{array}{l}-0.020^{* * *} \\
(-4.68)\end{array}$ & $\begin{array}{l}-0.020^{* * *} \\
(-4.59)\end{array}$ & $\begin{array}{l}-0.028^{* * *} \\
(-7.05)\end{array}$ & $\begin{aligned} & *-0.028 \\
&(-6.94)\end{aligned}$ & $\mid \begin{array}{l}-0.220^{* * * *} \\
(-7.63)\end{array}$ & $\begin{array}{l}-0.219^{* * *} \\
(-7.65)\end{array}$ & $\begin{array}{l}-6.316^{* * *} \\
(-6.93)\end{array}$ & $\begin{array}{l}-6.043 * * * \\
(-6.62)\end{array}$ & $\begin{array}{l}-3.234 * * * \\
(-10.20)\end{array}$ & $\begin{array}{l}-3.187 * * * \\
(-10.06)\end{array}$ & $\begin{array}{l}-1.570^{* * *} \\
(-9.86)\end{array}$ & $\begin{array}{l}-1.544^{* * *} \\
(-9.69)\end{array}$ \\
\hline $\begin{array}{l}\text { PLAYER'S } \\
\text { CHARACTER }\end{array}$ & & & & & & & & & & & & \\
\hline AGE & $\mid \begin{array}{l}-0.201 \\
(-0.58)\end{array}$ & $\begin{array}{l}-0.167 \\
(-0.48)\end{array}$ & $\begin{array}{l}0.028 \\
(0.09)\end{array}$ & $\begin{array}{l}0.112 \\
(0.35)\end{array}$ & $\begin{array}{l}5.801 * * \\
(2.52)\end{array}$ & $\begin{array}{l}6.272 * * * \\
(2.72)\end{array}$ & $\begin{array}{l}113.429 \\
(1.22)\end{array}$ & $\begin{array}{l}140.402 \\
(1.50)\end{array}$ & $\begin{array}{l}62.155^{* *} \\
(2.45)\end{array}$ & $\begin{array}{l}68.440^{* * *} \\
(2.68)\end{array}$ & $\begin{array}{l}34.717 * * * \\
(2.73)\end{array}$ & $\begin{array}{l}37.626^{* * *} \\
(2.94)\end{array}$ \\
\hline AGE SQ & $\begin{array}{l}0.005 \\
(1.07)\end{array}$ & $\begin{array}{l}0.005 \\
(0.99)\end{array}$ & $\begin{array}{l}-0.001 \\
(-0.14)\end{array}$ & $\begin{array}{l}-0.002 \\
(-0.37)\end{array}$ & $\begin{array}{l}-0.092^{* * *} \\
(-2.70)\end{array}$ & $\begin{array}{l}-0.094 * * * \\
(-2.74)\end{array}$ & $\begin{array}{l}-2.135 \\
(-1.32)\end{array}$ & $\begin{array}{l}-2.753^{*} \\
(-1.68)\end{array}$ & $\begin{array}{l}-1.012 * * * \\
(-2.70)\end{array}$ & $\begin{array}{l}-1.106^{* * *} \\
(-2.91)\end{array}$ & $\begin{array}{l}-0.604 * * * \\
(-3.21)\end{array}$ & $\begin{array}{l}-0.651 \\
(-3.41)\end{array}$ \\
\hline POSITION & Yes & Yes & Yes & Yes & Yes & Yes & Yes & Yes & Yes & Yes & Yes & Yes \\
\hline TEAM & No & Yes & No & Yes & No & Yes & No & Yes & No & Yes & No & Yes \\
\hline SEASON & Yes & Yes & Yes & Yes & Yes & Yes & Yes & Yes & Yes & Yes & Yes & Yes \\
\hline PLAYER & Yes & Yes & Yes & Yes & Yes & Yes & Yes & Yes & Yes & Yes & Yes & Yes \\
\hline \begin{tabular}{|l|} 
F-Test joint significance \\
$($ REL. \& ABOLUTE INC.)
\end{tabular} & $151.62 * * *$ & * $101.37 * * *$ & $81.49^{* * *}$ & $82.63^{* * *}$ & * $151.23 * * *$ & * $122.27 * * *$ & $61.79 * * *$ & $49.60^{* * *}$ & $168.73 * * *$ & $133.67 * * *$ & $154.95 * * *$ & $124.34 * * *$ \\
\hline R-Squared & 0.280 & 0.296 & 0.178 & 0.196 & 0.289 & 0.318 & 0.177 & & 0.274 & 0.297 & 0.269 & 0.291 \\
\hline Prob > F & 0.000 & 0.000 & 0.000 & 0.000 & 0.000 & 0.000 & 0.000 & 0.000 & 0.000 & 0.000 & 0.000 & 0.000 \\
\hline Groups (Players) & 768 & 768 & 768 & 768 & 768 & 768 & 562 & 562 & 768 & 768 & 768 & 768 \\
\hline Number of Observations & 2143 & 2143 & 2143 & 2143 & 2143 & 2143 & 1387 & 1387 & 2143 & 2143 & 2143 & 2143 \\
\hline
\end{tabular}

Notes: ${ }^{* * *}$ and ${ }^{* * *}$ denote statistical significance at the $10 \%, 5 \%$ and $1 \%$ level. $t$-statistics in parentheses. ${ }^{a}$ Without including SQ ABSOLUTE VALUE. 
Table 2: The Effect of Positional Concerns within the Team on Performance (Past Earnings)

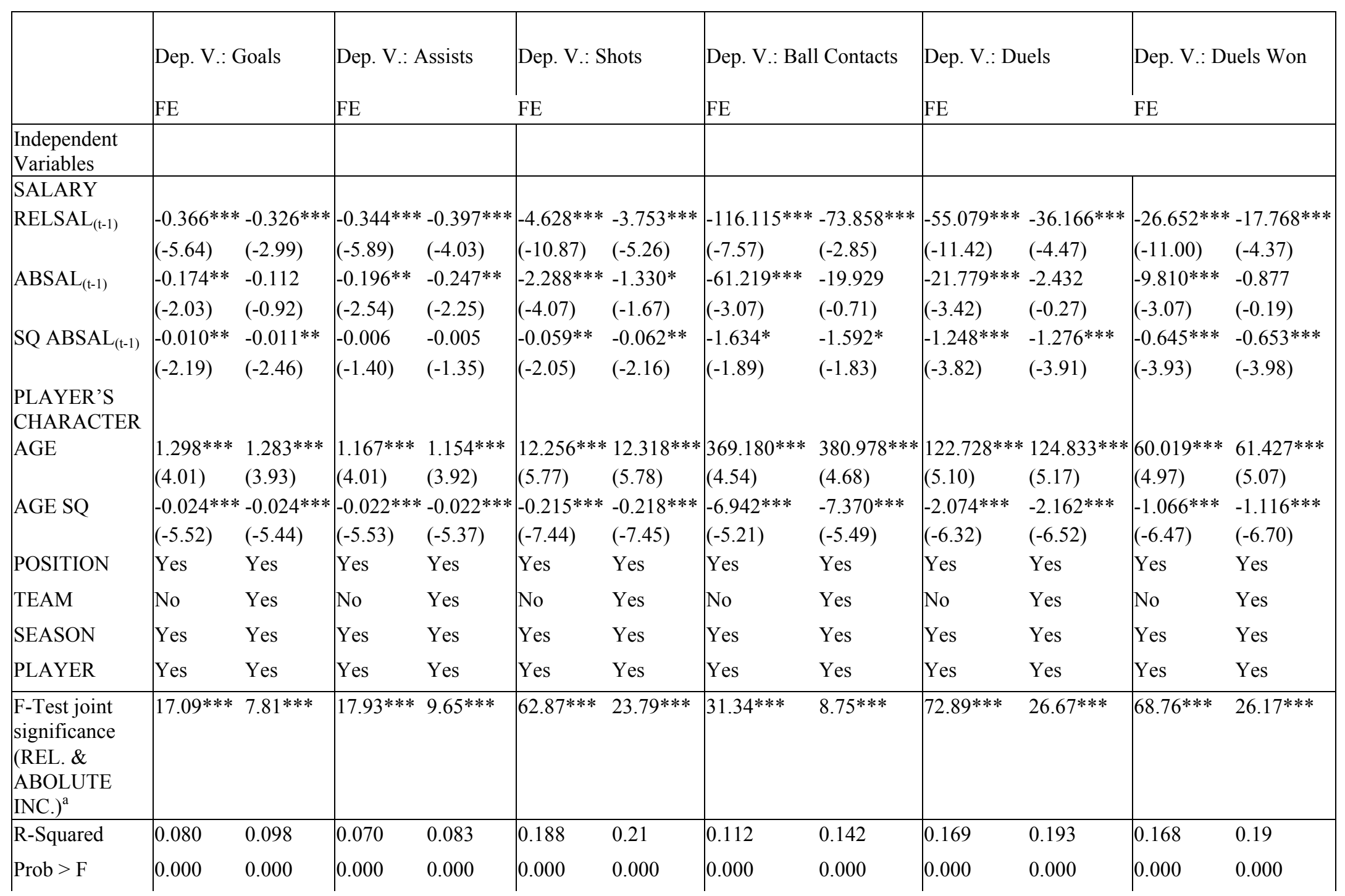




\begin{tabular}{|c|c|c|c|c|c|c|c|c|c|c|c|c|}
\hline & 1040 & 1040 & 1040 & 1040 & |1040 & 1040 & 774 & 774 & 1040 & 1040 & 1040 & 1040 \\
\hline $\begin{array}{l}\text { Number of } \\
\text { Observations }\end{array}$ & 2833 & 2833 & 2833 & 2833 & 2833 & 2833 & 1869 & 1869 & 2833 & 2833 & 2833 & 2833 \\
\hline
\end{tabular}


Table 3: League Players as the Reference Group and Robustness Analysis

\begin{tabular}{|c|c|c|c|c|c|c|c|c|c|c|}
\hline \multicolumn{11}{|c|}{$\begin{array}{l}\text { REFERENCE GROUP: AVERAGE INCOME OF ALL THE LEAGUE PLAYERS (PER SEASON) } \\
\end{array}$} \\
\hline \multirow[t]{2}{*}{ Dep.Variable } & \multicolumn{3}{|c|}{ Model: FE Future Income } & \multicolumn{2}{|c|}{ RELSAL (t+1) } & \multicolumn{2}{|c|}{ ABSAL (t+1) } & \multicolumn{2}{|c|}{ SQ. ABSAL (t+1) } & \multirow[b]{2}{*}{ F-test } \\
\hline & Player & Time & Team & Coeff. & t-value & Coeff. & t-value & Coeff. & t-value & \\
\hline Goals & Yes & No & No & $-1.017 * * *$ & -6.19 & -0.044 & -0.26 & $-0.019 * * *$ & -4.41 & $106.89 * * *$ \\
\hline Goals & Yes & No & Yes & $-0.996 * * *$ & -6.03 & -0.013 & -0.08 & $-0.018 * * *$ & -4.32 & $109.98 * * *$ \\
\hline Assists & Yes & No & No & $-0.661 * * *$ & -4.37 & 0.188 & 1.21 & $-0.028 * * *$ & -7.10 & $91.46^{* * *}$ \\
\hline Assists & Yes & No & Yes & $-0.685 * * *$ & -4.48 & 0.176 & 1.12 & $-0.028 * * *$ & -7.03 & $94.40 * * *$ \\
\hline Shots & Yes & No & No & $-5.872 * * *$ & -5.23 & 1.562 & 1.36 & $-0.235^{* * *}$ & -8.02 & $127.45 * * *$ \\
\hline Shots & Yes & No & Yes & $-5.983 * * *$ & -5.42 & 1.572 & 1.38 & $-0.231 * * *$ & -8.13 & $139.73 * * *$ \\
\hline Ball Contacts & Yes & No & No & -50.682 & -1.51 & $124.069 * * *$ & 3.57 & $-6.474 * * *$ & -7.14 & $59.18 * * *$ \\
\hline Ball Contacts & Yes & No & Yes & $-67.648 * *$ & -2.01 & $104.260 * * *$ & 2.98 & $-6.260 * * *$ & -6.97 & $57.76^{* * *}$ \\
\hline Duels & Yes & No & No & $-45.693 * * *$ & -3.69 & $41.084 * * *$ & 3.24 & $-3.294 * * *$ & -10.18 & $138.64 * * *$ \\
\hline Duels & Yes & No & Yes & $-49.607 * * *$ & -4.07 & $38.432 * * *$ & 3.06 & $-3.234 * * *$ & -10.29 & $151.34 * * *$ \\
\hline Duels Won & Yes & No & No & $-22.629 * * *$ & -3.66 & $20.142 * * *$ & 3.17 & $-1.608 * * *$ & -9.94 & $134.89 * * *$ \\
\hline Duels Won & Yes & No & Yes & $-24.835 * * *$ & -4.06 & $18.484 * * *$ & 2.94 & $-1.578 * * *$ & -10.00 & $145.65 * * *$ \\
\hline Dep. Variable & \multicolumn{3}{|c|}{ Model: FE Past Income } & \multicolumn{2}{|c|}{ RELSAL (t-1) } & \multicolumn{2}{|c|}{ ABSAL (t-1) } & \multicolumn{2}{|c|}{ SQ. ABSAL (t-1) } & \\
\hline Goals & Yes & No & Yes & $-0.649 * * *$ & -2.81 & -0.343 & -1.46 & $-0.014 * * *$ & -3.21 & $13.16^{* * *}$ \\
\hline Goals & Yes & No & No & $-0.571 * *$ & -2.47 & -0.341 & -1.45 & $-0.012 * * *$ & -2.72 & $8.32 * * *$ \\
\hline Assists & Yes & No & Yes & $-0.534 * *$ & -2.56 & -0.311 & -1.46 & $-0.008 * *$ & -2.05 & $9.17 * * *$ \\
\hline Assists & Yes & No & No & $-0.507 * *$ & -2.44 & -0.329 & -1.55 & $-0.008^{*}$ & -1.92 & $6.83 * *$ \\
\hline Shots & Yes & No & Yes & $-4.961 * * *$ & -3.24 & -1.796 & -1.15 & $-0.089 * * *$ & -3.08 & $28.22 * * *$ \\
\hline Shots & Yes & No & No & $-4.075 * * *$ & -2.60 & -1.711 & -1.07 & $-0.074 * *$ & -2.51 & $15.93 * * *$ \\
\hline Ball Contacts & Yes & No & Yes & -43.906 & -0.96 & 27.772 & 0.60 & $-2.208 * *$ & -2.54 & $11.43 * * *$ \\
\hline Ball Contacts & Yes & No & No & -34.197 & -0.74 & 23.522 & 0.50 & $-1.897 * *$ & -2.16 & $7.36^{* * *}$ \\
\hline Duels & Yes & No & Yes & -26.987 & -1.56 & 14.613 & 0.83 & $-1.591 * * *$ & -4.88 & $33.85 * * *$ \\
\hline Duels & Yes & No & No & -16.124 & -0.91 & 15.670 & 0.86 & $-1.408 * * *$ & -4.19 & $18.99 * * *$ \\
\hline Duels Won & Yes & No & Yes & -12.298 & -1.42 & 8.806 & 1.00 & $-0.822 * * *$ & -5.01 & $34.33 * * *$ \\
\hline Duels Won & Yes & No & No & -7.196 & -0.81 & 9.304 & 1.02 & $-0.738 * * *$ & -4.38 & $20.30 * * *$ \\
\hline \multicolumn{11}{|c|}{ Models controlling for games played per season } \\
\hline Dep. Variable & \multicolumn{3}{|c|}{ Model: FE Future Income } & \multicolumn{2}{|c|}{ RELSAL (t+1) } & \multicolumn{2}{|c|}{ ABSAL (t+1) } & SQ. ABSA & $L(t+1)$ & \\
\hline Goals & Yes & No & Yes & $-0.894 * * *$ & -5.65 & -0.225 & -1.40 & -0.007 & -1.61 & $51.95 * * *$ \\
\hline Assists & Yes & No & Yes & $-0.538 * * *$ & -3.78 & -0.043 & -0.30 & $-0.014 * * *$ & -3.83 & $32.91 * * *$ \\
\hline Shots & Yes & No & Yes & $-3.829 * * *$ & -4.39 & -0.538 & -0.61 & $-0.075 * * *$ & -3.31 & $39.45 * * *$ \\
\hline Ball Contacts & Yes & No & Yes & -22.058 & -1.20 & 10.856 & 0.58 & $-1.336^{* * *}$ & -2.69 & $6.32 * * *$ \\
\hline Duels & Yes & No & Yes & $-18.904 * * *$ & -3.04 & 5.832 & 0.93 & $-0.907 * * *$ & -5.61 & $40.33 * * *$ \\
\hline Duels Won & Yes & No & Yes & $-9.032 * * *$ & -2.80 & 2.604 & 0.80 & $-0.415 * * *$ & -4.95 & $33.26 * * *$ \\
\hline Dep. Variable & Model: & E Past & come & RELSAL ( $t$ - & & ABSAL (t-1 & & SQ. ABSA & $L(t-1)$ & \\
\hline Goals & Yes & No & Yes & $-0.378^{*}$ & -1.83 & $-0.369 *$ & -1.76 & -0.003 & -0.76 & 1.68 \\
\hline Assists & Yes & No & Yes & -0.279 & -1.53 & $-0.336^{*}$ & -1.81 & 0.002 & 0.66 & 1.86 \\
\hline Shots & Yes & No & Yes & $-2.345^{* *}$ & -2.12 & $-2.050^{*}$ & -1.82 & 0.017 & 0.81 & $2.44 *$ \\
\hline Ball Contacts & Yes & No & Yes & 16.254 & 0.71 & 10.427 & 0.45 & 0.478 & 1.09 & 0.46 \\
\hline Duels & Yes & No & Yes & 6.732 & 0.83 & 11.305 & 1.38 & -0.205 & -1.32 & 2.18 \\
\hline Duels Won & Yes & No & Yes & 4.648 & 1.1 & 7.144* & 1.67 & -0.126 & -1.56 & $2.69 *$ \\
\hline & Models & contro & g for gam & es played pe & season $R$ & EFERENCE & GROUP: & ТЕАМMA & TES & \\
\hline Dep. Variable & Model: & E Futu & Income & RELSAL ( $t$ & & ABSAL (t+1 & & SQ. ABSA & $L(t+1)$ & \\
\hline Goals & Yes & Yes & Yes & $-0.181 * *$ & -2.04 & $0.521 * * *$ & 4.88 & $-0.008^{*}$ & -1.83 & $47.49 * * *$ \\
\hline Assists & Yes & Yes & Yes & -0.045 & -0.56 & $0.456^{* * *}$ & 4.74 & $-0.014 * * *$ & -3.82 & $29.79 * * *$ \\
\hline Shots & Yes & Yes & Yes & $-2.200 * * *$ & -4.53 & $1.225 * *$ & 2.10 & $-0.073 * * *$ & -3.20 & $43.43 * * *$ \\
\hline Ball Contacts & Yes & Yes & Yes & 0.013 & 0.00 & $31.176^{* *}$ & 2.27 & $-1.202 * *$ & -2.41 & $5.56^{* * *}$ \\
\hline Duels & Yes & Yes & Yes & $-10.643 * * *$ & -3.07 & $16.302 * * *$ & 3.91 & $-0.971 * * *$ & -5.99 & $47.36^{* * *}$ \\
\hline Duels Won & Yes & Yes & Yes & -2.971 & -1.65 & $9.507 * * *$ & 4.38 & $-0.443 * * *$ & -5.25 & $36.33 * * *$ \\
\hline Dep. Variable & Model: & E Past & come & RELSAL (t & & ABSAL (t-1 & & SQ. ABSA & $L(t-1)$ & \\
\hline Goals & Yes & Yes & Yes & -0.158 & -1.61 & -0.131 & -1.19 & -0.004 & -0.99 & 1.31 \\
\hline Assists & Yes & Yes & Yes & $-0.234 * * *$ & -2.68 & $-0.265 * * *$ & -2.73 & 0.001 & 0.38 & $4.06^{* *}$ \\
\hline Shots & Yes & Yes & Yes & $-2.059 * * *$ & -3.91 & $-1.518 * *$ & -2.59 & 0.008 & 0.35 & $8.13 * * *$ \\
\hline Ball Contacts & Yes & Yes & Yes & $-32.697 * *$ & -2.50 & $-34.967 * *$ & -2.46 & 0.323 & 0.74 & $3.36^{* *}$ \\
\hline Duels & Yes & Yes & Yes & $-11.280 * * *$ & -2.93 & -5.191 & -1.21 & -0.248 & -1.59 & $6.23 * * *$ \\
\hline Duels Won & Yes & Yes & Yes & $-5.390 * * *$ & -2.69 & -2.250 & -1.01 & $-0.142 *$ & -1.75 & $5.60 * * *$ \\
\hline
\end{tabular}

Notes: All other variables included. F-test: Joint significance of the two variables RELATIVE INCOME and ABSOLUTE INCOME, ${ }^{* * *}$ and $* * *$ denote statistical significance at the $10 \%, 5 \%$ and $1 \%$ level. 
Table 4: Income Inequality and Positional Concern

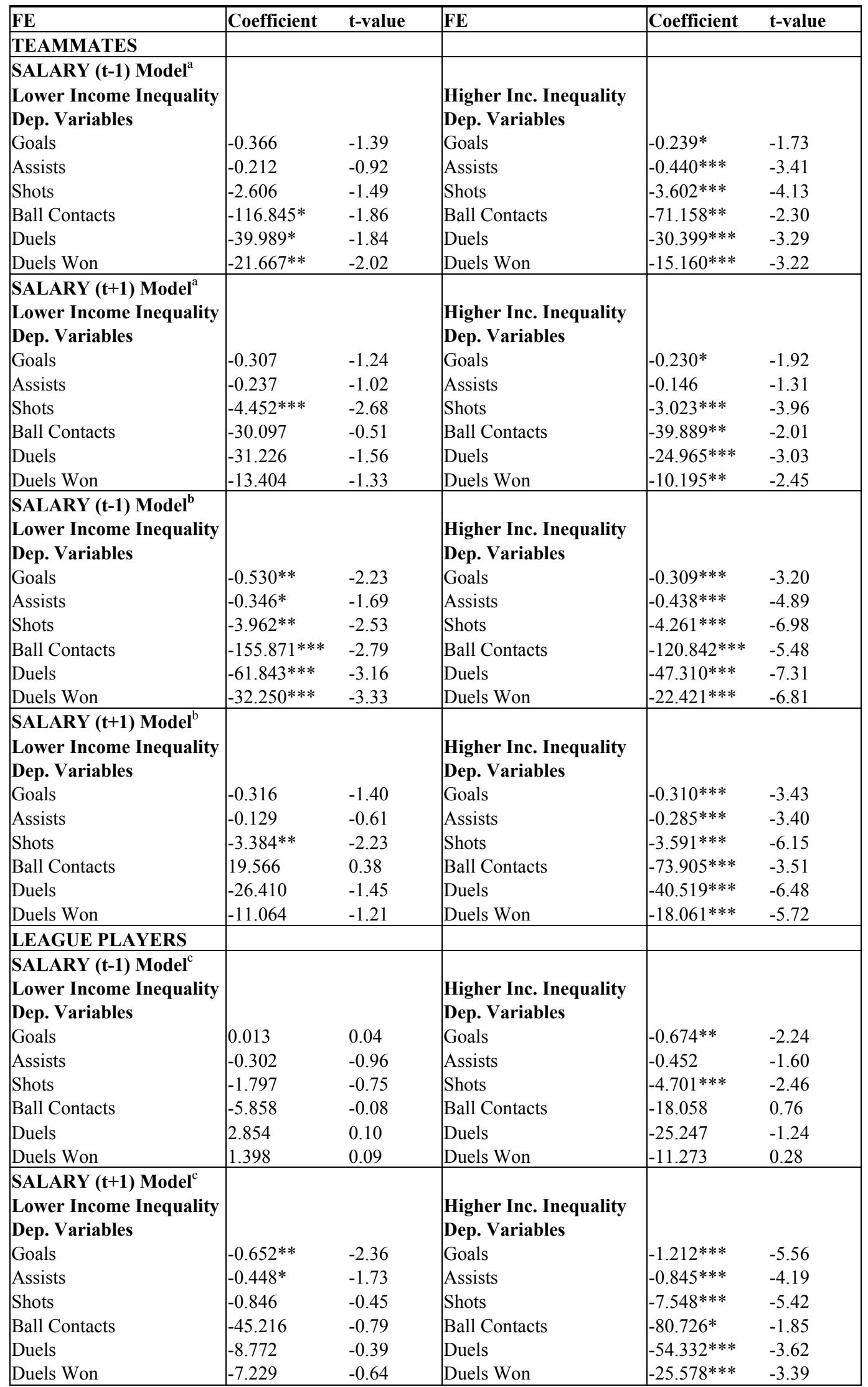

Notes: All other factors controlled for. Robust standard errors. ${ }^{*}, *$ and $* * *$ denote statistical significance at the $10 \%, 5 \%$ and $1 \%$ level. ${ }^{\text {a }}$ Reference group teammates, player, team and time fixed effects. ${ }^{b}$ Reference group teammates, player and time fixed effects. ${ }^{c}$ Reference group league players, player and team fixed effects. 
Table 5: Newcomers and Positional Concerns

\begin{tabular}{|c|c|c|c|c|c|}
\hline FE & Coefficient & t-value & FE & Coefficient & t-value \\
\hline \multicolumn{6}{|l|}{ TEAMMATES } \\
\hline \multicolumn{6}{|l|}{ SALARY (t-1) Model ${ }^{\text {a }}$} \\
\hline Not Changed Teams & & & Changed Teams & & \\
\hline Dep. Variables & & & Dep. Variables & & \\
\hline Goals & $-0.361 * * *$ & -3.01 & Goals & -1.191 & -1.60 \\
\hline Assists & $-0.357 * * *$ & -3.21 & Assists & -1.125 & -1.65 \\
\hline Shots & $-3.212 * * *$ & -4.15 & Shots & -8.741 & -1.57 \\
\hline Ball Contacts & $-63.125 * *$ & -2.20 & Ball Contacts & -280.877 & -1.34 \\
\hline Duels & $-28.105 * * *$ & -3.18 & Duels & -51.586 & -0.85 \\
\hline Duels Won & $-13.536 * * *$ & -3.03 & Duels Won & -26.033 & -0.92 \\
\hline \multicolumn{6}{|l|}{ SALARY (t+1) Model $^{\mathrm{a}}$} \\
\hline Not Changed Teams & & & Changed Teams & & \\
\hline Dep. Variables & & & Dep. Variables & & \\
\hline Goals & $-0.204 *$ & -1.96 & Goals & $-1.491 * *$ & -2.31 \\
\hline Assists & -0.095 & -0.98 & Assists & -0.737 & -1.16 \\
\hline Shots & $-2.672 * * *$ & -3.99 & Shots & $-10.491 *$ & -1.99 \\
\hline Ball Contacts & -25.523 & -1.08 & Ball Contacts & -14.125 & -0.05 \\
\hline Duels & $-23.292 * * *$ & -3.13 & Duels & -54.299 & -0.92 \\
\hline Duels Won & $-9.042 * *$ & -2.41 & Duels Won & -17.175 & -0.62 \\
\hline \multicolumn{6}{|l|}{ SALARY (t-1) Model ${ }^{\mathrm{b}}$} \\
\hline Not Changed Teams & & & Changed Teams & & \\
\hline Dep. Variables & & & Dep. Variables & & \\
\hline Goals & $-0.406^{* * *}$ & -3.77 & Goals & -0.755 & -1.12 \\
\hline Assists & $-0.379 * * *$ & -3.81 & Assists & $-1.110^{*}$ & -1.84 \\
\hline Shots & $-3.472 * * *$ & -4.99 & Shots & $-8.632 *$ & -1.76 \\
\hline Ball Contacts & $-57.953 * *$ & -2.33 & Ball Contacts & $-359.850 * *$ & -2.08 \\
\hline Duels & $-28.147 * * *$ & -3.54 & Duels & -68.301 & -1.28 \\
\hline Duels Won & $-13.465 * * *$ & -3.35 & Duels Won & -33.770 & -1.36 \\
\hline \multicolumn{6}{|l|}{ SALARY (t+1) Model $^{\text {b }}$} \\
\hline Not Changed Teams & & & Changed Teams & & \\
\hline Dep. Variables & & & Dep. Variables & & \\
\hline Goals & $-0.397 * * *$ & -4.39 & Goals & $-1.098^{*}$ & -2.00 \\
\hline Assists & $-0.222 * * *$ & -2.64 & Assists & -0.721 & -1.33 \\
\hline Shots & $-3.360 * * *$ & -5.83 & Shots & $-8.493 *$ & -1.96 \\
\hline Ball Contacts & $-43.793 * *$ & -2.22 & Ball Contacts & 41.141 & 0.18 \\
\hline Duels & $-28.123 * * *$ & -4.37 & Duels & -40.691 & -0.85 \\
\hline Duels Won & $-12.080 * * *$ & -3.72 & Duels Won & -13.716 & -0.61 \\
\hline \multicolumn{6}{|l|}{ LEAGUE PLAYERS } \\
\hline \multicolumn{6}{|l|}{ SALARY (t-1) Model ${ }^{\mathrm{c}}$} \\
\hline Not Changed Teams & & & Changed Teams & & \\
\hline Dep. Variables & & & Dep. Variables & & \\
\hline Goals & $-0.606 * *$ & -2.48 & Goals & 1.988 & 1.17 \\
\hline Assists & $-0.460 * *$ & -2.03 & Assists & -2.103 & -1.37 \\
\hline Shots & $-4.320 * * *$ & -2.73 & Shots & -1.510 & -0.12 \\
\hline Ball Contacts & -24.440 & -0.49 & Ball Contacts & -82.542 & -0.23 \\
\hline Duels & -19.254 & -1.07 & Duels & -73.472 & -0.54 \\
\hline Duels Won & -7.524 & -0.82 & Duels Won & -37.963 & -0.60 \\
\hline \multicolumn{6}{|l|}{ SALARY $(t+1)$ Model } \\
\hline Not Changed Teams & & & Changed Teams & & \\
\hline Dep. Variables & & & Dep. Variables & & \\
\hline Goals & $-1.006^{* * *}$ & -5.53 & Goals & -0.298 & -0.24 \\
\hline Assists & $-0.643 * * *$ & -3.80 & Assists & -1.106 & -0.92 \\
\hline Shots & $-5.606^{* * *}$ & -4.79 & Shots & 0.926 & 0.09 \\
\hline Ball Contacts & $-76.927 * *$ & -2.07 & Ball Contacts & 367.631 & 1.17 \\
\hline Duels & $-45.470 * * *$ & -3.49 & Duels & 83.814 & 0.79 \\
\hline Duels Won & $-22.373 * * *$ & -3.41 & Duels Won & 43.037 & 0.86 \\
\hline
\end{tabular}

Notes: All other factors controlled for. Robust standard errors. $*, * *$ and $* * *$ denote statistical significance at the $10 \%, 5 \%$ and $1 \%$ level. ${ }^{a}$ Reference group teammates, player, team and time fixed effects. ${ }^{\mathrm{b}}$ Reference group teammates, player and team fixed effects. ${ }^{\mathrm{c}}$ Reference group league players, player and team fixed effects. 
Table 6: Top Teams and Positional Concern

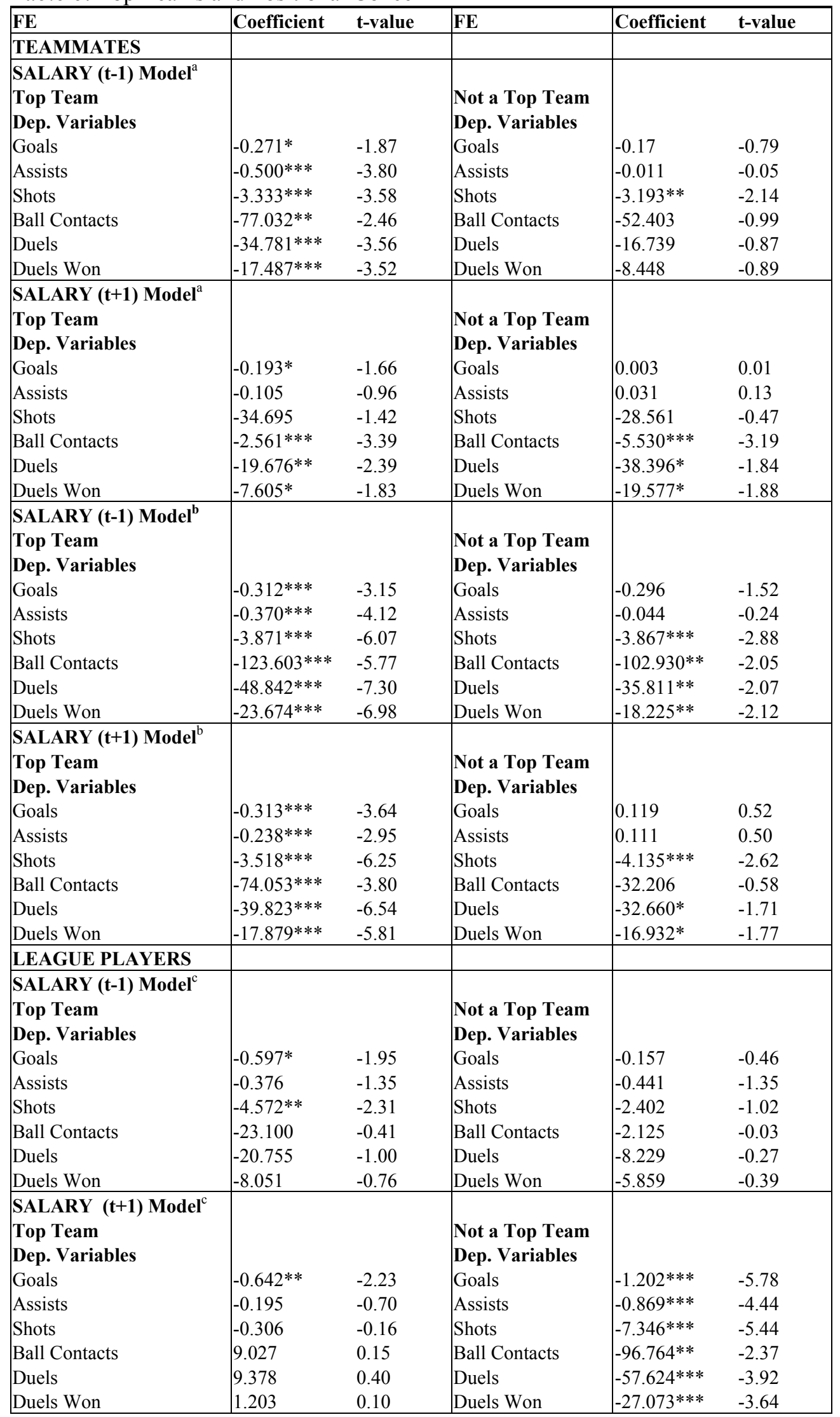

Notes: All other factors controlled for. Robust standard errors. *** and *** denote statistical significance at the $10 \%, 5 \%$ and $1 \%$ level. ${ }^{\text {a }}$ Reference group teammates, player, team and time fixed effects. ${ }^{b}$ Reference group teammates, player and time fixed effects. ${ }^{\mathrm{c}}$ Reference group league players, player and team fixed effects. 
Table 7: 2SLS Estimations

\begin{tabular}{|c|c|c|c|c|c|c|c|c|}
\hline \multirow{2}{*}{$2 \mathrm{SLS}^{\mathrm{a}}$} & \multirow{2}{*}{\begin{tabular}{|l|} 
Salary \\
Relative income
\end{tabular}} & \multirow{2}{*}{ Joint signif. } & \multicolumn{2}{|c|}{$\begin{array}{l}\text { First Stage Regressions } \\
\text { (relative and absolute income) }\end{array}$} & \multicolumn{2}{|c|}{$\begin{array}{l}\text { Test of excluded } \\
\text { instruments: }\end{array}$} & \multirow[b]{2}{*}{$\begin{array}{l}\text { Anderson canon. } \\
\text { corr. likel. ratio }\end{array}$} & \multirow[b]{2}{*}{$\begin{array}{l}\text { Anderson-Rubin } \\
\text { test }\end{array}$} \\
\hline & & & $\begin{array}{l}\text { Relative income: } \\
\text { gini coeff. }(t)\end{array}$ & \begin{tabular}{|l} 
Absolute \\
income: home \\
spectators (t)
\end{tabular} & $\begin{array}{l}\text { relative } \\
\text { income }\end{array}$ & \begin{tabular}{|l|} 
absolute \\
income
\end{tabular} & & \\
\hline \multicolumn{9}{|l|}{$\begin{array}{l}\text { TEAMMATES } \\
\text { MODEL: INC. }(\mathrm{t}+\mathbf{1})\end{array}$} \\
\hline Goals & $-0.703 * * *$ & $10.65^{* * *}$ & $2.213^{* * *}$ & $8.78 \mathrm{E}-07 * * *$ & $17.96^{* * *}$ & $19.94 * * *$ & $20.857 * * *$ & $4.24 * *$ \\
\hline Assists & $-0.538 * * *$ & $8.10 * *$ & $2.213^{* * *}$ & $8.78 \mathrm{E}-07 * * *$ & $17.96^{* * *}$ & $19.94 * * *$ & $20.857 * * *$ & $3.69 * *$ \\
\hline Shots & $-6.048 * * *$ & $19.69 * * *$ & $2.213 * * *$ & $8.78 \mathrm{E}-07 * * *$ & $17.96^{* * *}$ & $19.94 * * *$ & $20.857 * * *$ & $8.30 * * *$ \\
\hline Ball Contacts & $-131.684 * * *$ & $7.74 * *$ & $3.026 * * *$ & $4.03 \mathrm{E}-07 * * *$ & $13.41^{* * *}$ & $27.65^{* * * *}$ & $24.663 * * *$ & $3.62 * *$ \\
\hline Duels & $-69.165^{* * *}$ & $20.35^{* * *}$ & $2.213^{* * *}$ & $8.78 \mathrm{E}-07 * * *$ & $17.96^{* * *}$ & $19.94 * * *$ & $20.857 * * *$ & $8.97 * * *$ \\
\hline Duels Won & $-31.493 * * *$ & $16.44 * * *$ & $2.213^{* * *}$ & $8.78 \mathrm{E}-07 * * *$ & $17.96^{* * *}$ & $19.94 * * *$ & $20.857 * * *$ & $7.28 * * *$ \\
\hline $2 \operatorname{SLS}^{\mathrm{b}}$ & Salary & & \multicolumn{2}{|c|}{$\begin{array}{l}\text { First Stage Regressions } \\
\text { (relative and absolute income) }\end{array}$} & \multicolumn{2}{|c|}{$\begin{array}{l}\text { Test of excluded } \\
\text { instruments: }\end{array}$} & & \\
\hline & Relative income & Joint signif. & $\begin{array}{l}\text { Relative income: } \\
\text { foreigner }\end{array}$ & \begin{tabular}{|l} 
Absolute \\
income: home \\
spectators (t-2)
\end{tabular} & $\begin{array}{l}\text { relative } \\
\text { income }\end{array}$ & $\begin{array}{l}\text { absolute } \\
\text { income }\end{array}$ & $\begin{array}{l}\text { Anderson canon. } \\
\text { corr. likel. ratio }\end{array}$ & $\begin{array}{l}\text { Anderson-Rubin } \\
\text { test }\end{array}$ \\
\hline \multicolumn{9}{|l|}{$\begin{array}{l}\text { TEAMMATES } \\
\text { MODEL: INC. (t-1) }\end{array}$} \\
\hline Goals & $-0.994 * * *$ & $8.20^{* *}$ & $-0.444 * * *$ & $2.96 \mathrm{E}-06^{* * *}$ & $12.74 * * *$ & $43.58^{* * * *}$ & $22.924 * * *$ & $3.63^{* *}$ \\
\hline Assists & $-0.598 *$ & 3.99 & $-0.444 * * *$ & $2.96 \mathrm{E}-06^{* * *}$ & $12.74 * * *$ & $43.58 * * *$ & $22.924 * * *$ & 1.71 \\
\hline Shots & $-6.916^{* * *}$ & $8.33^{* *}$ & $-0.444 * * *$ & 2.96E-06*** & $12.74 * * *$ & $43.58^{* * *}$ & $22.924 * * *$ & $3.23 * *$ \\
\hline Ball Contacts & $-215.242 * *$ & $15.02 * * *$ & $-0.496 * * *$ & $2.17 \mathrm{E}-06 * * *$ & $11.09^{* * *}$ & $18.30^{* * * *}$ & $21.507 * * *$ & $7.14 * * *$ \\
\hline Duels & $-124.682 * * *$ & $21.54 * * *$ & $-0.444 * * *$ & $2.96 \mathrm{E}-06 * * *$ & $12.74 * * *$ & $43.58^{* * * *}$ & $22.924 * * *$ & $13.19 * * *$ \\
\hline Duels Won & $-60.260 * * *$ & $22.49 * * *$ & $-0.444 * * *$ & 2.96E- $06^{* * *}$ & $12.74 * * *$ & $43.58 * * *$ & $22.924 * * *$ & $13.90^{* * *}$ \\
\hline
\end{tabular}

Notes: All other variables included. ${ }^{a}$ Individual fixed effects. ${ }^{b}$ Team fixed effects. Joint signif.: Joint significance of the two variables RELATIVE INCOME and ABSOLUTE INCOME. *,** and *** denote statistical significance at the $10 \%, 5 \%$ and $1 \%$ level. 
Table 8: Granger Causality Test

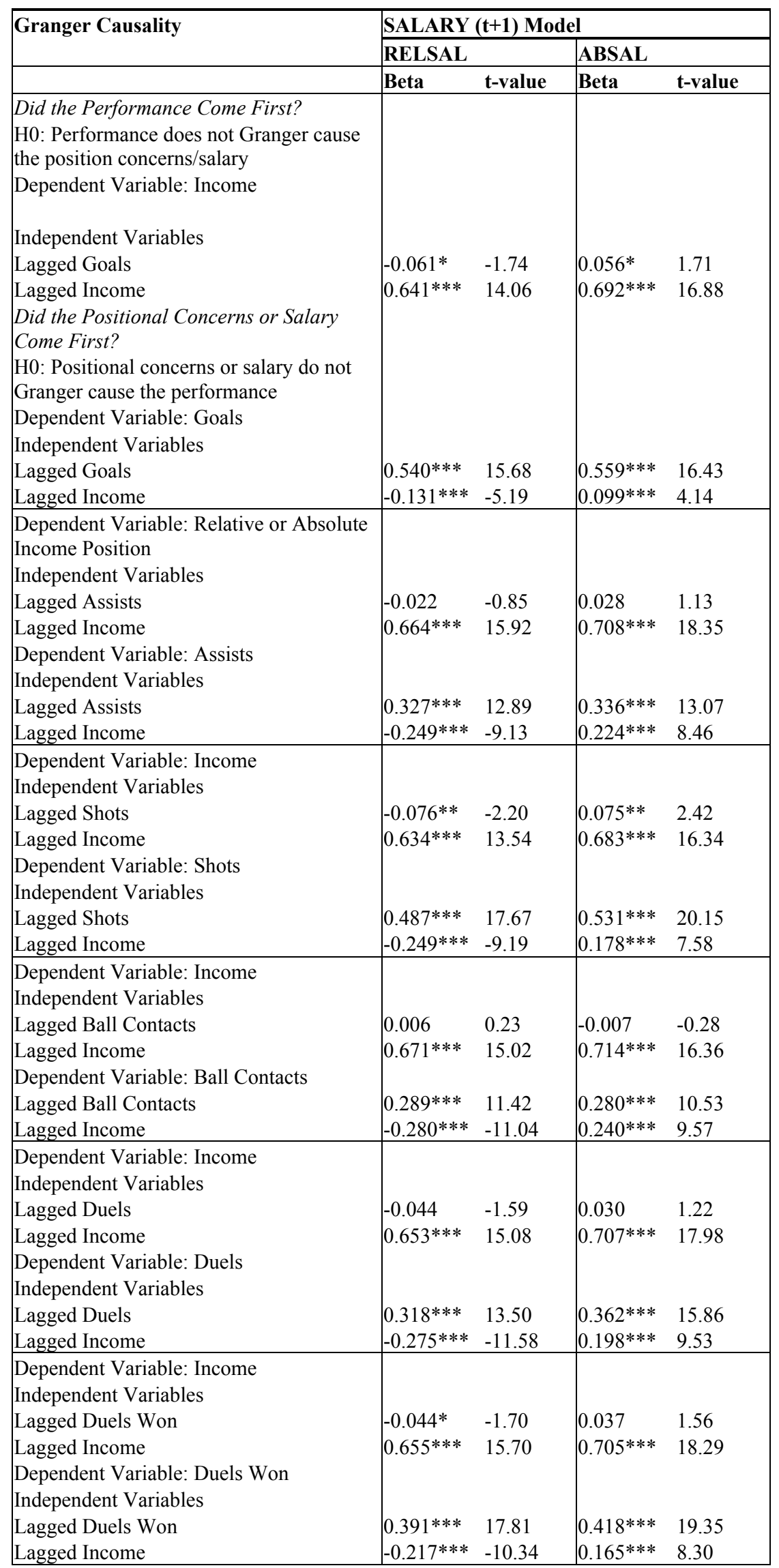

Notes: Robust standard errors. ${ }^{*}, * *$ and $* * *$ denote statistical significance at the $10 \%, 5 \%$ and $1 \%$ level. 


\section{APPENDIX}

Table A1

Football's Richest Players (March 2004)

\begin{tabular}{llc}
\hline \multicolumn{1}{c}{ Player } & \multicolumn{1}{c}{ Club } & € Millions Per Year \\
\hline Beckham & Real Madrid & 22.2 \\
Zidane & Real Madrid & 14.05 \\
Nakata & Bologna & 11.8 \\
Ronaldo & Real Madrid & 11.09 \\
Raul & Real Madrid & 11.09 \\
Vieri & Inter & 10.35 \\
Owen & Liverpool & 9.6 \\
Keane & Manchester United & 8.87 \\
Figo & Real Madrid & 8.87 \\
Del Piero & Juventus & 7.4 \\
\hline
\end{tabular}

Source: www.soccer-europe.com

Table A2

Summary Statistics

\begin{tabular}{lllll}
\hline & Mean & Std. Dev. & Min. & Max. \\
\hline Goals & 2.026 & 3.239 & 0.00 & 28.00 \\
Assists & 2.002 & 2.576 & 0.00 & 19.00 \\
Shots & 21.881 & 23.128 & 0.00 & 148.00 \\
Ball Contacts & 747.388 & 573.759 & 0.00 & 2464.00 \\
Duels & 158.540 & 118.390 & 0.00 & 639.00 \\
Duels Won & 317.008 & 230.543 & 0.00 & 1236.00 \\
RELSAL(t-1) & -0.056 & 2.118 & -20.13 & 7.63 \\
ABSAL(t-1) & 2.855 & 2.541 & 0.05 & 25.00 \\
RELSAL(t+1) & -0.035 & 2.434 & -19.73 & 7.48 \\
ABSAL(t+1) & 3.390 & 2.748 & 0.20 & 25.00 \\
AGE & 26.557 & 4.154 & 17.00 & 40.00 \\
GAMES PLAYED & 18.333 & 10.055 & 1.00 & 34.00 \\
MINUTES PLAYED & 1299.562 & 898.462 & 1.00 & 3060.00 \\
\hline
\end{tabular}


Table A3

Outlier Analysis

\begin{tabular}{|c|c|c|c|c|c|c|c|c|c|c|}
\hline \multicolumn{11}{|c|}{ REFERENCE GROUP: AVERAGE INCOME OF ALL THE LEAGUE PLAYERS (PER SEASON) } \\
\hline & Player & Time & Team & Coeff. & t-value & Coeff. & t-value & Coeff. & t-value & F-test \\
\hline Dep. Variable & \multicolumn{3}{|c|}{$\begin{array}{l}\text { Model: Outlier Analysis } \\
\text { Future Income }\end{array}$} & \multicolumn{2}{|c|}{ REL. INCOME (t+1) } & \multicolumn{2}{|c|}{ ABS. INCOME (t+1) } & \multicolumn{2}{|c|}{ SQ. ABS. INC. $(\mathrm{t}+1)$} & \\
\hline Goals & Yes & No & Yes & $-0.530 * * *$ & -8.15 & $0.162 * *$ & 2.40 & $-0.530 * * *$ & -8.15 & $180.34 * * *$ \\
\hline Assists & Yes & No & Yes & $-0.479 * * *$ & -6.93 & $0.217 * * *$ & 3.03 & $-0.479 * * *$ & -6.93 & $158.98 * * *$ \\
\hline Shots & Yes & No & Yes & $-6.972 * * *$ & -11.85 & $1.664 * * *$ & 2.72 & $-0.302 * * *$ & -12.93 & $347.46^{* * *}$ \\
\hline Ball Contacts & Yes & No & Yes & $-83.224 * * *$ & -2.75 & $208.468 * * *$ & 6.74 & $-13.310 * * *$ & -18.94 & $356.15 * * *$ \\
\hline Duels & Yes & No & Yes & $-60.191 * * *$ & -8.97 & $42.712 * * *$ & 6.12 & $-4.186 * * *$ & -15.68 & $361.31 * * *$ \\
\hline Duels Won & Yes & No & Yes & $-31.626 * * *$ & -9.08 & $20.159 * * *$ & 5.57 & $-2.068 * * *$ & -14.94 & $341.42 * * *$ \\
\hline Dep. Variable & \multicolumn{3}{|c|}{$\begin{array}{l}\text { Model: Outlier Analysis } \\
\text { Past Income }\end{array}$} & \multicolumn{2}{|c|}{ REL. INCOME (t-1) } & \multicolumn{2}{|c|}{ ABS. INCOME (t-1) } & \multicolumn{2}{|c|}{ SQ. ABS. INC. (t-1) } & \\
\hline Goals & Yes & No & Yes & $-0.417 * * *$ & -8.47 & $0.086^{*}$ & 1.73 & $-0.017 * * *$ & -7.68 & $143.53 * * *$ \\
\hline Assists & Yes & No & Yes & $-0.443 * * *$ & -7.80 & 0.061 & 1.07 & $-0.013 * * *$ & -5.06 & $110.10 * * *$ \\
\hline Shots & Yes & No & Yes & $-6.334 * * *$ & -12.23 & 0.685 & 1.31 & $-0.246 * * *$ & -10.73 & $258.29 * * *$ \\
\hline Ball Contacts & Yes & No & Yes & $-0.530 * * *$ & -8.15 & $0.162 * *$ & 2.40 & $-8.303 * * *$ & -10.80 & $180.34 * * *$ \\
\hline Duels & Yes & No & Yes & $-58.102 * * *$ & -8.70 & $29.922 * * *$ & 4.45 & $-3.400 * * *$ & -11.49 & $230.53 * * *$ \\
\hline Duels Won & Yes & No & Yes & $-108.492 * * *$ & -3.78 & $114.480^{* * *}$ & 3.91 & $-1.708 * * *$ & -11.24 & $192.19 * * *$ \\
\hline \multicolumn{11}{|c|}{ REFERENCE GROUP: TEAMMATES } \\
\hline Dep. Variable & \multicolumn{3}{|c|}{ Model: Outlier Analysis } & \multicolumn{2}{|c|}{ REL. INCOME (t+1) } & \multicolumn{2}{|c|}{ ABS. INCOME (t+1) } & \multicolumn{2}{|c|}{ SQ. ABS. INC. $(t+1)$} & \\
\hline Goals & Yes & Yes & Yes & $-0.270 * * *$ & -4.43 & $0.457 * * *$ & 6.48 & $-0.017 * * *$ & -7.75 & $42.87 * * *$ \\
\hline Assists & Yes & Yes & Yes & $-0.151 * *$ & -2.30 & $0.556 * * *$ & 7.31 & $-0.013 * * *$ & -5.16 & $158.60 * * *$ \\
\hline Shots & Yes & Yes & Yes & $-3.638 * * *$ & -6.62 & $5.105 * * *$ & 8.02 & $-0.263 * * *$ & -11.45 & $360.35 * * *$ \\
\hline Ball Contacts & Yes & Yes & Yes & $-62.963 * * *$ & -3.19 & $229.632 * * *$ & 10.19 & $-81.414 * * *$ & -3.12 & $363.03 * * *$ \\
\hline Duels & Yes & Yes & Yes & $-32.133 * * *$ & -5.10 & $73.929 * * *$ & 10.12 & $-3.508 * * *$ & -11.85 & $392.97 * * *$ \\
\hline Duels Won & Yes & Yes & Yes & $-14.037 * * *$ & -4.27 & $38.849 * * *$ & 10.21 & $-1.758 * * *$ & -11.55 & $357.64 * * *$ \\
\hline Dep. Variable & \multicolumn{3}{|c|}{ Model: Outlier Analysis } & \multicolumn{2}{|c|}{ REL. INCOME (t-1) } & \multicolumn{2}{|c|}{ ABS. INCOME (t-1) } & \multicolumn{2}{|c|}{ SQ. ABS. INC. (t-1) } & \\
\hline Goals & Yes & Yes & Yes & $-0.193 * * *$ & -3.42 & $0.315 * * *$ & 5.04 & $-0.017 * * *$ & -7.75 & $142.37 * * *$ \\
\hline Assists & Yes & Yes & Yes & $-0.167 * *$ & -2.55 & $0.346 * * *$ & 4.77 & $-0.013 * * *$ & -5.16 & $106.89 * * *$ \\
\hline Shots & Yes & Yes & Yes & $-4.272 * * *$ & -7.2 & $3.040 * * *$ & 4.62 & $-0.263 * * *$ & -11.45 & $278.30 * * *$ \\
\hline Ball Contacts & Yes & Yes & Yes & $-81.414 * * *$ & -3.12 & $142.602 * * *$ & 5.09 & $-81.414 * * *$ & -3.12 & $195.27 * * *$ \\
\hline Duels & Yes & Yes & Yes & $-46.818 * * *$ & -6.12 & $43.462 * * *$ & 5.12 & $-3.508 * * *$ & -11.85 & $251.05 * * *$ \\
\hline Duels Won & Yes & Yes & Yes & $-22.777 * * *$ & -5.79 & $22.521 * * *$ & 5.16 & $-1.758 * * *$ & -11.55 & $238.06^{* * *}$ \\
\hline
\end{tabular}




\section{REFERENCES}

Abowd, J. M. (1990). Does Performance-Based Managerial Compensation Affect Corporate Performance? Industrial and Labor Relations Review. 43: 52S-73S.

Akerlof, G. A. and J. L. Yellen (1990). The Fair Wage-Effort Hypothesis and Unemployment, Quarterly Journal of Economics. 105: 255-284.

Alpizar, F. F. Carlsson and O. Johansson-Stenman (2005). How Much Do We Care About Absolute Versus Relative Income and Consumption? Journal of Economic Behavior and Organization. 56: 405-421.

Asch, B. J. (1990). Do Incentives Matter? The Case of the Navy Recruiters, Industrial and Labor Relations Review. 43: 89S-105S.

Becker, B. E. and M. A. Huselid (1992). The Incentive Effects of Tournament Compensation Systems, Administrative Science Quarterly. 37: 336-350.

Becker, G. S. (1974). A Theory of Social Interaction, Journal of Political Economy. 82: 1063-1093.

Boskin M. and E. Sheshinski (1978). Optimal Redistribution Taxation When Individual Welfare Depends Upon Relative Income, Quarterly Journal of Economics. 92: 589-601.

Breusch, T. and A. Pagan (1980). The Lagrange Multiplier Test and Its Applications to Model Specification in Econometrics, Review of Economic Studies. 47: 239-253.

Carmichael, F., D. Forrest and R. Simmons (1999). The Labour Market in Associate Football: Who Gets Transferred and for How Much? Bulletin of Economics Research. 51: 1-26.

Clark, A. and A. Oswald (1996). Satisfaction and Comparison Income, Journal of Public Economics. 61: 359-81.

Davies, B., P. Downward and I. Jackson (1995). The Demand for Rugby League: Evidence from Causality Tests, Applied Economics. 27: 1003-1007.

Dobson, S. M. and J. A. Goddard (1998). Performance and Revenue in Professional League Football: Evidence from Granger Causality Tests, Applied Economics. 30: 1641-1651.

Dufour, M. (2003). Identification, Weak Instruments and Statistical Inference in Econometrics, Canadian Journal of Economics. 36: 767-808.

Dunn, J. R.and M. E. Schweitzer (2004). Too Good to be Trusted? Relative Performance, Envy and Trust, Academy of Management Best Conference Paper. CM: B1-6

Duesenberry, J. S. (1949). Income, Saving and the Theory of Consumer Behavior. Harvard: University of Harvard Press.

Easterlin, R. (1974). Does Economic Growth Improve the Human Lot? Some Empirical Evidence, in: P. A. David and M. W. Reder (eds.), Nations and Households in Economic Growth: Essays in Honor of Moses Abramovitz. New York: Academic Press: 89-125.

Easterlin, R. (1995). Will Raising the Incomes of All Increase the Happiness of All? Journal of Economic Behavior and Organization. 27: 35-47. 
Easterlin, R. A. (2001). Income and Happiness: Towards a Unified Theory, Economic Journal. 111: $465-484$

Ehrenberg, R. G. and M. L. Bognanno (1990a). Do Tournaments Have Incentive Effects? Journal of Political Economy. 98: 1307-1324.

Ehrenberg, R. G. and M. L. Bognanno (1990b). The Incentive Effects of Tournaments Revisited: Evidence from the European PGA Tour, Industrial and Labor Relations Review. 43: 74S$88 \mathrm{~S}$

Elster, J. (1991). Envy in Social Life, in: R. J. Zeckhauser (ed.), Strategy and Choice. Cambridge, Mass.: The MIT Press: 49-82.

Eschweiler, M. and M. Vieth (2004). Preisdeterminanten bei Spielertransfers in der FußballBundesliga. Zeitschrift für Betriebswirtschaft. 64: 671-692.

Fernie, S. and D. Metcalf (1999). It's Not What You Pay It's the Way that You Pay It and that's What Gets Results: Jockeys' Pay and Performance, Labour. 13: 385-411.

Ferrer-i-Carbonell, A. (2005). Income and Well-Being: An Empirical Analysis of the Comparison Income Effect, Journal of Public Economics. 89: 997-1019.

Festinger, L. (1954). A Theory of Social Comparison Processes, Human Relations. 7: 117-140.

Forrest, D. and R. Simmons (2002). Team Salaries and Playing Success in Sports: A Comparative Perspective, Zeitschrift für Betriebswirtschaft. 62: 221-237.

Frank, R. (1985). Choosing the Right Pond: Human Behaviour and the Quest for Status. Oxford: Oxford University Press.

Frank, R. H. (1991). Positional Externalities, in: R. J. Zeckhauser (ed.), Strategy and Choice. Cambridge, Mass.: The MIT Press: 25-47.

Frank, R. H. (1999). Luxury Fever: Why Money Fails to Satisfy in an Era of Excess. New York: The Free Press.

Frank, R. H. and P. J. Cook (1995). The Winner-Take-All Society. New York: Free Press.

Frank, R. H. and C. R. Sunstein (2001). Cost-Benefit Analysis and Relative Position, University of Chicago Law Review. 68: 323-374.

Frey, B. S. (2005). Knight Fever: Towards an Economics of Awards. CREMA Working Paper 200512, Basel, Center for Research in Economics, Management and the Arts.

Frey, B. S. and S. Meier (2004). Pro-Social Behavior in a Natural Setting, Journal of Economic Behavior and Organization. 54: 65-88.

Frey, B. S. and M. Osterloh (2005). Yes Managers Should be Paid Like Bureaucrats, Journal for Management Inquiry. 14: 96-111.

Frey, B. S. and A. Stutzer (2002a). Happiness and Economics. Princeton: Princeton University Press.

Frey, B. S. and A. Stutzer (2002b). What Can Economists Learn from Happiness Research? Journal of Economic Literature. 40: 402-435. 
Frey, B. S. and B. Torgler (2004). Taxation and Conditional Cooperation. CREMA Working Paper 2004-20, Basel, Center for Research in Economics, Management and the Arts.

Galbraith, J. K. (1958). The Affluent Society. Boston: Houghton-Mifflin.

Garcia-del-Barrio, P. and F. Pujol (2004). Pay and Performance in the Spanish Soccer League: Who Gets the Expected Monopsony Rents? Working Paper No. 05/04, Universidad de Navarra.

Gibbons, R. and K. Murphy (1990). Relative Performance Evaluation for Chief Executive Officers, Industrial and Labor Relations Review. 43: 30S-51S.

Granger, C. W. (1969). Investigating Causal Relations by Econometric Models and Cross-Spectral Methods, Econometrica. 37: 424-438.

Greene, J. R. and N. L. Stokey (1983). A Comparison of Tournaments and Contracts, Journal of Political Economy. 91: 349-365.

Groot, W. and H. M. van den Brink (1999). Overpayment and Earnings Satisfaction: An Application of an Ordered Response Tobit Model, Applied Economics Letters. 6: 235-238.

Grund, C. and Sliwka, D. (2005). Envy and Compassion in Tournaments, Journal of Economics \& Management Strategy. 14: 187-207.

Hall, A., G. Rudebusch and D. Wilcox (1996). Judging Instrument Relevance in Instrumental Variable Estimation, International Economic Review. 37: 283-298.

Hall, S., S. Szymanski and A. Zimbalist (2002). Testing Causality Between Team Performance and Payroll: The Cases of Major League Baseball and English Soccer, Journal of Sports Economics. 3: 149-168.

Hamilton, B. H., J. A. Nickerson and H. Owan (2003) Team Incentives and Worker Heterogeneity: An Empirical Analysis of the Impact of Teams on Productivity and Participation, Journal of Political Economy. 3: 465-98.

Hausman, J. A. (1978). Specification Tests in Econometrics, Econometrica. 46: 1251-1271.

Hübl, L. and D. Swieter (2002). Der Spielemarkt in der Fußball-Bundesliga. Zeitschrift für Betriebswirtschaft. Special Issue 72: 105-123.

Idson, T. L. and L. H. Kahane (2000). Team Effects on Compensation: An Application to Salary Determinants in the National Hockey League, Economic Inquiry. 38: 345-357.

Jensen, M. C. and K. J. Murphy (1990). Performance Pay and Top-Management Incentives, Journal of Political Economy. 98: 225-264.

Johansson-Stenman, O., F. Carlsson and D. Daruvala (2005). Measuring Future Grandparents' Preferences for Equality and Relative Standing, Economic Journal. 112: 362-383.

Kern, M. and B. Süssmuth (2003). Managerial Efficiency in German Top League Soccer, Discussion Paper No. 5, University of Munich, Germany.

Kirchsteiger, G. (1994). The Role of Envy in Ultimatum Games, Journal of Economic Behavior and Organization. 25: 373-389. 
Knack, S. (1999). Social Capital and the Quality of Government: Evidence from the U.S. States,

World Bank Policy Research Working Paper Series No. 2504.

Landers, R. M., J. B. Rebitzer and L. J. Taylor (1996). Rat Race Redux: Adverse Selection in the Determination of Work Hours in Law Firms, American Economic Review. 86: 329-348.

Layard, R. (2003). Income and Happiness: Rethinking Economic Policy, Lecture 2, London School of Economics, London (see cep.lse.ac.uk/events/lectures/layard/RL040303.pdf).

Lazear, E. P. (1998) Personnel Economics for Managers. New York: Wiley.

Lazear, E. P. (2000). Performance Pay and Productivity, American Economic Review. 90: 1346-1361.

Lazear, E. P. and S. Rosen (1981). Rank-Order Tournaments as Optimum Labor Contracts, Journal of Political Economy. 89: 841-864.

Lehmann, E. E. and G. G. Schulze (2005). What Does it Take to Be a Star? The Role of Performance and the Media for German Soccer Players, unpublished manuscript.

Lehmann, E. E. and J. Weigand (1998). Wieviel Phantasie braucht die Fußballaktie? Zeitschrift für Betriebswirtschaft, Ergänzungsheft. 68: 101-119.

Lehmann, E. E. and J. Weigand (1999). Determinanten der Entlohnung von Profifußballspielern Eine empirische Analyse für die deutsche Bundesliga, Betriebswirtschaftliche Forschung und Praxis. 51: 124-135.

Loewenstein, G., T. O’ Donoghue and M. Rabin (2003). Projection Bias in Predicting Future Utility, Quarterly Journal of Economics. 118: 1209-1248.

Lucifora, C. and R. Simmons (2003). Superstar Effects in Sport: Evidence From Italian Soccer, Journal of Sports Economics. 4: 35-55.

Luttmer, E. F. P. (2005). Neighbors As Negatives: Relative Earnings and Well-Being, Quarterly Journal of Economics. 120: 963-1002.

Lynch, J. G. and J. S. Zax (1998). Prizes, Selection and Performance in Arabian Horse Racing, Working Paper No. 98-26, University of Colorado at Boulder.

Lynch, J. G. and J. S. Zax (2000). The Rewards to Running: Prize Structure and Performance in Professional Road Racing, Journal of Sports Economics. 1: 323-340.

Maloney, M. and R. E. McCormick (2000). The Response of Workers to Wages in Tournaments: Evidence from Foot Races, Journal of Sports Economics. 1: 99-123.

Marshall, A. (1961). Principles of Economics. London: Macmillan.

Marx, K. (1849). Wage Labour and Capital, in: K. Marx and F. Engel, Selected Works. Vol.1, Moscow: Progress Publishers.

McBride, M. (2001). Relative-Income Effects on Subjective Well-Being in the Cross-Section, Journal of Economic Behavior and Organization. 45: 251-278.

McLaughlin, K. J. (1988). Aspects of Tournament Models: A Survey, in R. G. Ehrenberg (ed.), Research in Labor Economics Vol. 9. Greenwich, CT: JAI: PP. 225-256. 
Melton, M. and T. S. Zorn (2000). An Empirical Test of Tournament Theory: The Senior PGA Tour, Managerial Finance. 26: 16-32.

Nalebuff, B. J. and J. E. Stiglitz (1983). Prizes and Incentives: Towards a General Theory of Compensation and Competition, RAND Journal of Economics. 14: 21-43.

Neumark, D. and A. Postlewaite (1998). Relative Income Concerns and the Rise in Married Women's Employment, Journal of Public Economics. 70: 157-183.

Ng, Y.-K. (1987). Relative-Income Effects and the Appropriate Level of Public Expenditure, Oxford Economic Papers. 39: 293-300.

Ng, Y.-K. (1997). A Case for Happiness, Cardinalism, and Interpersonal Comparison, Economic Journal. 107:1848-1858.

Ng, Y.-K. (2003). From Preference to Happiness: Towards a More Complete Welfare Economics, Social Choice and Welfare. 20: 307-350.

O'Keefe, M., W. K. Viscusi and R. J. Zeckhauser (1984). Economic Contests: Comparative Reward Schemes, Journal of Labor Economics. 2: 27-56.

Orszag, J. M. (1994). A New Look at Incentive Effects and Golf Tournaments, Economics Letters. 46: $77-88$

Parrott, W.G. and R.H. Smith (1993). Distinguishing the Experiences of Envy and Jealousy, Journal of Personality and Social Psychology. 64: 906-920.

Pollak, R. A. (1976). Interdependent Preferences, American Economic Review. 66: 309-320.

Prendergast, C. (1999). The Provision of Incentives in Firms, Journal of Economic Literature. 42: 7 63.

Rees, A. (1992). The Tournament as a Model for Executive Compensation, Journal of Post Keynesian Economics. 14: 567-571.

Rosen, S. (1981). The Economics of Superstars, Journal of Political Economy. 79: 1302-1319.

Rosen, S. (1988). Promotion, Elections, and Other Contests, Journal of Institutional and Theoretical Economics. 144: 73-90.

Schelling, T. C. (1978). Micromotives and Macrobehavior. New York: W. W. Norton.

Schoeck, H. (1966). Envy: A Theory of Social Behavior. Indianapolis: Liberty Fund.

Scitovsky, T. (1976). The Joyless Economy: An Inquiry Into Human Satisfaction and Consumer Dissatisfaction. Oxford: Oxford University Press.

Senik, C. (2004). Revitalizing Relativizing Income, Delta Working Paper 2004-17, Paris.

Shea, J. (1997). Instrument Relevance in Multivariate Linear Models: A Simple Measure, Review of Economics \& Statistics. 79: 348-352.

Smith, A. (1759/1976). Theory of Moral Sentiments. Oxford: Clarendon Press.

Solnick, S. J. and D. Hemenway (1998). Is More Always Better?: A Survey on Positional Concerns, Journal of Economic Behavior and Organization. 37: 373-383.

Stouffer, S. A. (1949). The American Soldier. Princeton: Princeton University Press. 
Stutzer, A. (2004). The Role of Income Aspirations in Individual Happiness, Journal of Economic Behavior and Organization. 54: 89-109.

Sunde, U. (2003). Potential, Prizes and Performance: Testing Tournament Theory with Professional Tennis Data. IZA Discussion Paper Series, No. 947, Bonn, Germany.

Szymanski, S. and T. Kuypers (1999). The English Football Industry: Profit, Performance and Industrial Structure, International Review of Applied Economics. 11: 135-153.

Torgler, B. (2004). The Economics of the FIFA Football Worldcup, KYKLOS. 2: 287-300.

Torgler, B. (2006). 'La Grande Boucle': Determinants of Success at the Tour de France, forthcoming in: Journal of Sports Economics.

Tsou, M. W. and J. T. Liu (2001). Happiness and Domain Satisfaction in Taiwan, Journal of Happiness Studies. 2: 269-88.

Tversky, A. and D. Griffin (1991). Endowment and Contrast in Judgments of Well-Being, in R. J. Zeckhauser (ed.), Strategy and Choice. Cambridge, Mass.: The MIT Press: 297-318.

Veblen, T. (1899). The Theory of the Leisure Class. New York: MacMillan.

Walker, I. and T. F. Pettigrew (1984). Relative Deprivation Theory: An Overview and Conceptual Critique, British Journal of Social Psychology. 23: 301-310.

Zeckhauser, R. J. (ed.) (1991). Strategy and Choice. Cambridge: The MIT Press.

1 Abowd (1990), Jensen and Murphy (1990), and Gibbons and Murphy (1990) investigate the relationship between pay and managerial performance or corporate returns, or Asch (1990) for Navy recruiters' reactions to different incentive plans.

2 See also, for example, Nalebuff and Stiglitz (1983), Green and Stokey (1983), O'Keefe, Viscusi and Zeckhauser (1984), Rosen (1988), McLaughlin (1988), Rees (1992), Prendergast (1999).

3 There are also some studies that test the theory of tournaments outside the context of sport (see, e.g., Knoeber and Thurman 1994, Eriksson 1999, Rees 1992).

4 It was not possible to consider the year 1997 because no proxy for players' salaries is available.

5 It is possible to investigate further reference groups. Perhaps players compare themselves to the best-paid player on the team or one can argue that players compare themselves with other players that have the same position within the game. On the other hand, one can argue that a superstar might be the best reference group. Workers may acknowledge the distinction to a superstar and are therefore content with variations in pay that match variations in ability.

6 We also used the ratio, instead of the differences, and the results remain robust.

7 Summary statistics are provided in Table A2 in the Appendix.

8 Information from the Kicker Sportmagazin has been used for empirical research studies in the past (see for instance Eschweiler and Vieth (2004), Huebl and Swieter (2002), Lehmann and Weigand (1998, 1999) and Lehmann and Schulze (2005)).

9 The publicly available data from Transfermarkt.de was only available for the season 2003/2004. Historical data was not available, as the Internet site just started to collect this information in 2005. Furthermore, Transfermarkt.de covers only a limited number of players in the German Bundesliga. 
10 Experts' estimations of players' salaries after the previous season. As mentioned previously, we check the robustness of the results using the ratio instead of the difference to measure the relative income position.

${ }^{11}$ Considering estimations without controlling for the games or minutes played are insofar justifiable, as playing in a game is already a signaling of performance (good performance in the past and the training).

12 For a general discussion see Knack (1999). 